\title{
Characterization of Ricin and R. communis Agglutinin Reference Materials
}

Sylvia Worbs ${ }^{1}$, Martin Skiba ${ }^{1}$, Martin Söderström ${ }^{2}$, Marja-Leena Rapinoja ${ }^{2}$, Reinhard Zeleny ${ }^{3}$, Heiko Russmann ${ }^{4}$, Heinz Schimmel ${ }^{3}$, Paula Vanninen ${ }^{2}$, Sten-Åke Fredriksson ${ }^{5}$ and Brigitte G. Dorner ${ }^{1, *}$

Received: 4 September 2015; Accepted: 22 October 2015; Published: 26 November 2015

Academic Editor: Daniel Gillet

1 Biological Toxins, Centre for Biological Threats and Special Pathogens, Robert Koch Institute, Seestr. 10, 13353 Berlin, Germany; worbss@rki.de (S.W.); skibam@rki.de (M.S.)

2 VERIFIN (Finnish Institute for Verification of the Chemical Weapons Convention), Department of Chemistry, University of Helsinki, A.I. Virtasen aukio 1, Helsinki 05600, Finland; martin.soderstrom@helsinki.fi (M.S.); marja-leena.rapinoja@helsinki.fi (M.-L.R.); paula.vanninen@helsinki.fi (P.V.)

3 European Commission, Joint Research Centre, Institute for Reference Materials and Measurements, Retieseweg 111, 2440 Geel, Belgium; reinhard.zeleny@ec.europa.eu (R.Z.); heinz.schimmel@ec.europa.eu (H.S.)

4 Bundeswehr Research Institute for Protective Technologies and NBC Protection, Humboldtstr. 100, 29633 Munster, Germany; heikorussmann@bundeswehr.org

5 FOI, Swedish Defence Research Agency, CBRN Defence and Security, Cementvagen 20, 90182 Umeå, Sweden; sten-ake.fredriksson@foi.se

* Correspondence: DornerB@rki.de; Tel.: +49-30-18754-2500; Fax: +49-30-1810-754-2501

\begin{abstract}
Ricinus communis intoxications have been known for centuries and were attributed to the toxic protein ricin. Due to its toxicity, availability, ease of preparation, and the lack of medical countermeasures, ricin attracted interest as a potential biological warfare agent. While different technologies for ricin analysis have been established, hardly any universally agreed-upon "gold standards" are available. Expert laboratories currently use differently purified in-house materials, making any comparison of accuracy and sensitivity of different methods nearly impossible. Technically challenging is the discrimination of ricin from $R$. communis agglutinin (RCA120), a less toxic but highly homologous protein also contained in $R$. communis. Here, we established both highly pure ricin and RCA120 reference materials which were extensively characterized by gel electrophoresis, liquid chromatography-electrospray ionization-tandem mass spectrometry (LC-ESI MS/MS), and matrix-assisted laser desorption ionization-time of flight approaches as well as immunological and functional techniques. Purity reached $>97 \%$ for ricin and $>99 \%$ for RCA120. Different isoforms of ricin and RCA120 were identified unambiguously and distinguished by LC-ESI MS/MS. In terms of function, a real-time cytotoxicity assay showed that ricin is approximately 300-fold more toxic than RCA120. The highly pure ricin and RCA120 reference materials were used to conduct an international proficiency test.
\end{abstract}

Keywords: proficiency test; ricin; reference material

\section{Introduction}

Originally identified by Stillmark in 1888 [1], ricin is produced by Ricinus (R.) communis and is one of the most toxic plant toxins known today. It belongs to the family of type II ribosome-inactivating proteins [2]. As a prototype $\mathrm{AB}$ toxin, ricin consists of a sugar-binding $\mathrm{B}$ chain $(\sim 34 \mathrm{kDa})$ linked via a disulfide bond to the catalytically active A chain $(\sim 32 \mathrm{kDa})$ which acts as 
an RNA $N$-glycosidase, resulting in a holotoxin of about $65 \mathrm{kDa}[3,4]$. As lectin, the B chain mediates cell binding via different oligosaccharide residues on the cell surface, including $N$-acetylglucosamine and galactose residues found on glycolipids and glycoproteins [5-7]. Previously, oligosaccharides have been employed for the purification of ricin by affinity chromatography [8-10]. After internalization, the A-B heterodimer undergoes retrograde transport via the Golgi network to the endoplasmic reticulum where the heterodimer is reduced and separated into the two subchains [11,12]. The A chain is then transported into the cytosol and binds to the ribosome where it removes a single adenine from the $28 \mathrm{~S}$ rRNA, thus preventing further binding of elongation factors, inhibiting protein biosynthesis, and finally leading to cell death [13-15].

The understanding of ricin is complicated by the fact that, besides ricin, $R$. communis seeds contain the homologous but less toxic protein $R$. communis agglutinin, abbreviated RCA120 [6]. RCA120 is a $120 \mathrm{kDa}$ heterotetrameric protein consisting of two ricin-like heterodimers linked via a disulfide bond between the two A chains [16]. Different isoforms of ricin have been described, adding further complexity to the issue: the original isoform now termed ricin $\mathrm{D}$ is accompanied in most $R$. communis cultivars by the isoform ricin $\mathrm{E}$ which contains a hybrid $\mathrm{B}$ chain composed of the $N$-terminal part of the original ricin B chain and the C-terminal part of the RCA120 B chain ([17-19]).

Ricin and RCA120 show a high sequence homology of $93 \%$ and $84 \%$ between the A and B chains of ricin and RCA120, respectively [20]. Still, ricin is a potent toxin but a weak hemagglutinin, whereas RCA120 is only a weak toxin but a strong hemagglutinin [21,22]. Depending on the experimental system used, the difference in toxicity between ricin and RCA120 was described to be about 60-2000 times [8,22-24]. Accidental and intended R. communis intoxications in humans and animals have been known for centuries. The toxicity of ricin in vivo is estimated to be $1-20 \mathrm{mg} / \mathrm{kg}$ body weight when ingested and 1-10 $\mu \mathrm{g} / \mathrm{kg}$ body weight when delivered by inhalation or injection [4].

Both ricin and RCA120 are not single copy genes, but rather part of a larger ricin gene family encoding for seven full-length ricin or ricin-like proteins and several potential shorter gene products of unknown expression and function, indicating a greater variability than previously anticipated $[4,25,26]$. The seven full-length proteins of the ricin gene family have been found to inhibit protein synthesis similar to ricin itself $[4,26]$. Ricin contains four glycosylation sites, two on the A chain and two on the B chain [4,27], and additional heterogeneity of the molecule is based on different glycosylation patterns: it has been shown that variable toxicities of ricin isoforms have been correlated with different glycosylation levels [28,29]. Another level of complexity has recently been added by the description of heterogeneity in the deamidation pattern, the conversion rate of single asparagine residues to aspartic and isoaspartic acid [30].

Ricin and the ricin-producing plant are typical dual-use substances: $R$. communis is grown worldwide on an industrial scale as a source of castor oil which is-because of the high content of the unsaturated fatty acid ricinoleic acid and its favorable physico-chemical properties-a valued raw material for the production of lubricants, pharmaceuticals, cosmetics, paints, coatings, inks, and many other products. During the extraction process ricin accrues as a by-product of the oil's production [31]. Its high toxicity, availability, and the relative ease of extraction make ricin a potential agent for bioterrorism [32]. Consequently, ricin is listed as a category B agent of potential bioterrorism risk by the Centers for Disease Control and Prevention (CDC) [33]. Actually, ricin has been used for small-scale attacks such as the assassination of Georgi Markov [34,35]. High media coverage was gained by the ricin-containing threat letters sent in 2003 and 2013 to members of the U.S. Senate and the White House as well as to U.S. President Obama [36,37]. Additionally, ricin has a history of military use by different nations and was included in different weapons programs during World War II and later [36,38-40]. Therefore, ricin is a prohibited substance both under the Chemical Weapons Convention (CWC, schedule 1 compound) and the Biological Weapons Convention (BWC); its possession and production must be declared to the Organisation for the Prohibition of Chemical Weapons (OPCW), and it may be used only for strictly specified purposes defined in the CWC. 
Against the background of the toxin's potential misuse for terrorist, criminal, or military purposes, the rapid, sensitive, and ideally unambiguous detection of ricin is necessary. While different technologies for ricin detection and identification have been established using immunological, spectrometric, functional, or molecular approaches, hardly any universally agreed-upon "gold standards" are available [4]. No certified reference material is available, and expert laboratories currently use differently purified in-house materials as a standard, making any comparison of accuracy and sensitivity of different methods nearly impossible. Also there are open questions as to which methods have to be used and combined to obtain preliminary, confirmed, and unambiguous results. Depending on the task and scenario, the discrimination of ricin from the homologous RCA120 is important, as only ricin is recognized as a threat agent under the BWC and a schedule 1 component under the CWC. In the context of a forensic analysis it might be important to present information on purity and amount, biological activity, and potential source of a suspect sample.

In this work, we have established both highly pure ricin and RCA120 reference materials which were extensively characterized by biochemical, spectrometric, immunological, and functional techniques. Especially liquid chromatography-electrospray ionization-tandem mass spectrometry (LC-ESI MS/MS) was instrumental in differentiating the related ricin D, ricin E, and RCA120 from each other. Both materials were later used in the framework of the European Union (EU) project EQuATox (Establishment of quality assurance for the detection of biological toxins of potential bioterrorism risk [41]) funded under the European Community's Seventh Framework Programme to organize and conduct a large international proficiency test (PT, [42]).

\section{Results and Discussion}

Depending on the primary protein sequence and its specific glycosylation and deamidation level, ricin is a heterogeneous molecule with variable molecular weight, protein charge/isoelectric point, and toxicity [27-30]. Against this background, an important question is from which cultivar or plant variety ricin and the highly homologous RCA120 should be purified to generate well-characterized reference materials since any characteristic might be attributed to that particular toxin isolated from a selected cultivar and might not automatically be applied to toxins from other sources $[27,30]$. Commercially available ricin and RCA120 were purified from an unknown cultivar and also show variable purities: $96 \%$ purity for ricin was reported, but only $68 \%$ purity for RCA120 [43]. The question was discussed in the expert forum of the EQuATox consortium representing scientists from 35 laboratories and 20 countries internationally. Specifically, it was discussed whether the cultivar $R$. communis zanzibariensis should be used as toxin source which has been shown to contain ricin $\mathrm{D}$ only [44] or whether a cultivar like R. communis carmencita should be used which is known to contain both ricin D and ricin E isolectins. Ricin from R. communis zanzibariensis can be clearly differentiated from ricin purified from a panel of other cultivars and seems to be particular [27]. Therefore, it was decided to use a more representative cultivar as source of toxin, even if this meant to purify a mixture of ricin isolectins, namely $\mathrm{D}$ and $\mathrm{E}$.

To this end, ricin and RCA120 were prepared from the seeds of $R$. communis carmencita following previously published procedures $[8,45,46]$. Both protein preparations were thoroughly characterized, combining technically independent and complementary approaches to describe the purity, composition, and activity of both ricin and RCA120 using biochemical, spectrometric, immunological, and functional methods (Figure 1).

At the beginning of the study, a highly precise and accurate quantification of both purified protein preparations was important for the subsequent comparison of quantitative results reported in the proficiency test. It is known that different protein quantification methods such as Bradford assay [47], Lowry method [48], or amino acid analysis based on isotope dilution mass spectrometry [49] deliver variable results depending on the size and charge of the target protein, its amino acid composition, glycosylation pattern or other post-translational modifications, buffer 
conditions and potential impurities present in a protein sample [50,51]. Based on the facts that both protein preparations were determined to be highly pure glycoproteins (see Sections 2.1 and 2.2) and to have available well-established extinction coefficients for ricin and RCA120, it was decided to use the measurement of absorbance at $280 \mathrm{~nm}$ for quantification of the protein content. Based on the absorption measured at $280 \mathrm{~nm}$ and according to Lambert-Beer's law and the known extinction coefficients $\varepsilon=1.1615 \mathrm{~mL} \times \mathrm{mg}^{-1} \times \mathrm{cm}^{-1}$ for ricin [52] and $\varepsilon=1.17 \mathrm{~mL} \times \mathrm{mg}^{-1} \times \mathrm{cm}^{-1}$ for RCA120 [6], the protein concentrations were determined at $c$ (ricin) $=1.51 \pm 0.043 \mathrm{mg} / \mathrm{mL}$ and $c($ RCA120 $)=1.03 \pm 0.035 \mathrm{mg} / \mathrm{mL}$.

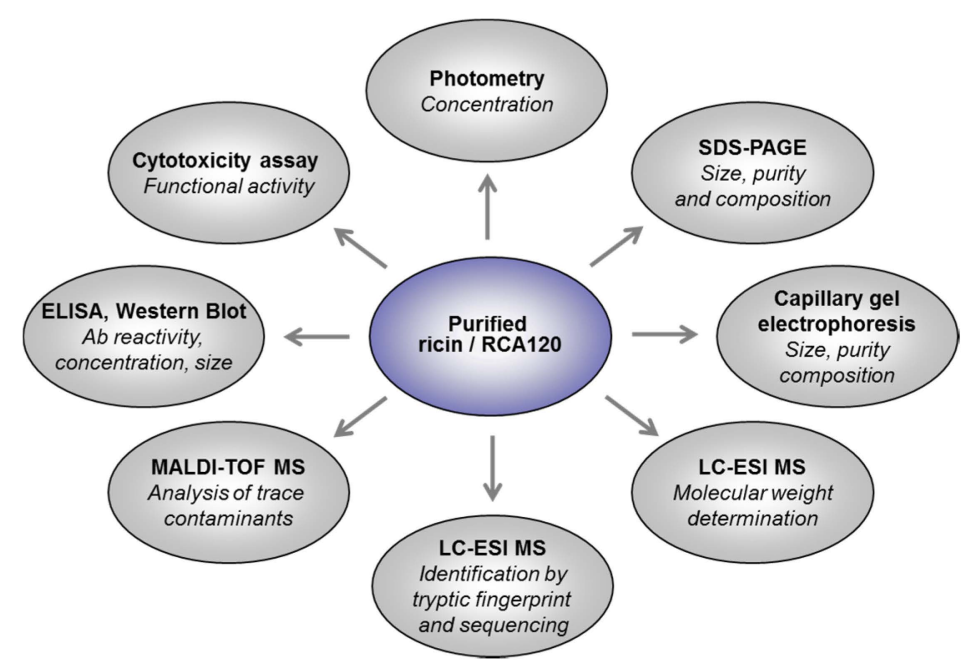

Figure 1. Schematic overview of technical approaches used to describe the purity, composition, and activity of highly purified ricin and RCA120 from R. communis carmencita.

\subsection{Size, Purity and Composition}

\subsubsection{Composition and Purity by Gel Electrophoresis}

In order to display an overview of the composition and purity of the ricin and RCA120 preparations, sodium dodecyl sulfate polyacrylamide gel electrophoresis (SDS-PAGE) and capillary gel electrophoresis (CGE) were performed as a first step. As displayed in Figure 2, both ricin and RCA120 preparations showed distinct, sharp bands upon separation in an SDS-PAGE and no degradation of proteins was observed. Non-reduced ricin was running at about $60 \mathrm{kDa}$, while non-reduced RCA120 was arbitrarily running at a higher molecular weight between $120 \mathrm{kDa}$ and $170 \mathrm{kDa}$. This behavior has been observed before for other preparations of RCA120 [6]. Under reducing conditions, ricin migrated in two bands of around 33 and $35 \mathrm{kDa}$, where the lower band has been shown to contain the ricin A chain and the upper band a higher glycosylated form of the ricin A chain plus the ricin B chain [51]. RCA120 was showing three bands of about 33-36 kDa, and the result was in good accord with previously reported data $[6,28,29,51]$.

For both protein preparations, a number of faint bands of lower molecular weight than the full-length toxins were observed by SDS-PAGE. These bands could potentially represent shorter fragments of ricin or RCA120, respectively, or completely unrelated proteins co-purified from $R$. communis. The identity of these trace contaminants was clarified by matrix-assisted laser desorption ionization-time of flight mass spectrometry (MALDI-TOF MS) analysis (see Section 2.2.2). 


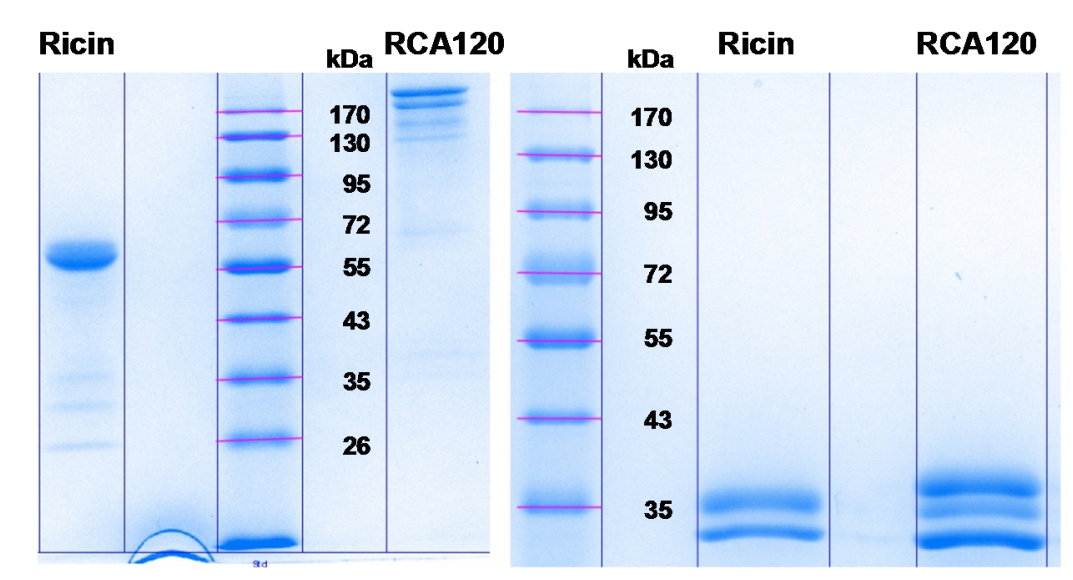

Figure 2. Protein separation of purified ricin and RCA120 from R. communis carmencita. 10\% SDS-PAGE of either purified ricin (3 $\mu$ g of ricin each) or purified RCA120 (5 $\mathrm{g}$ of RCA120 each) separated under non-reducing conditions (left panel) or under reducing conditions (right panel, use of $\beta$-mercaptoethanol as reducing agent) followed by staining with Coomassie Brilliant Blue.

As judged from the main protein bands, no significant cross-contamination of ricin with RCA120 or, vice versa, RCA120 with ricin was observed, and the purity was estimated to be $>95 \%$. Since this point was important for designing proper PT samples, it was further analyzed using CGE.

Figure 3 shows a CGE electropherogram of a crude extract of $R$. communis containing $R$. communis seed storage protein (SSP), ricin, and RCA120. The molecular weight of the analytes was evaluated by the instrument software using a series of molecular weight standards analyzed in each chip and the molecular weight markers present in the sample buffer. Electropherograms of the purified ricin preparation and the purified RCA120 preparation are shown in Figure 4. In the ricin preparation the peak doublet at 65-70 kDa was attributed to ricin. No peak from RCA120 - expected at $146 \mathrm{kDa}$ and a running time of around $40 \mathrm{~s}$-was observed (Figure $4 \mathrm{a}, \mathrm{b}$ ). To evaluate and confirm the CGE results, standard addition experiments were conducted. An amount of RCA120 corresponding to 5\% of the concentration of ricin was added to the purified ricin preparation. In Figure 4c, a peak near the detection limit was observed (marked with a green arrow), which indicates that the RCA120 content in the purified ricin sample was less than $5 \%$.

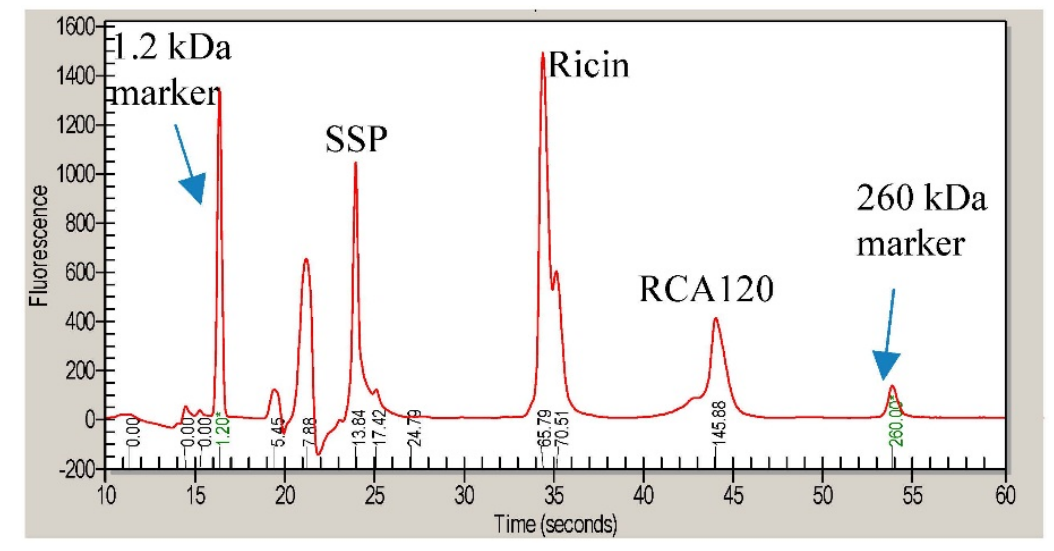

Figure 3. CGE analysis of a crude R. communis extract containing seed storage protein (SSP, $13 \mathrm{kDa})$, ricin (65 and $70 \mathrm{kDa})$, and RCA120 (146 kDa). Prior to analysis, the molecular weight markers at $1.2 \mathrm{kDa}$ and $260 \mathrm{kDa}$ were added for calibration. 
Ricin preparation
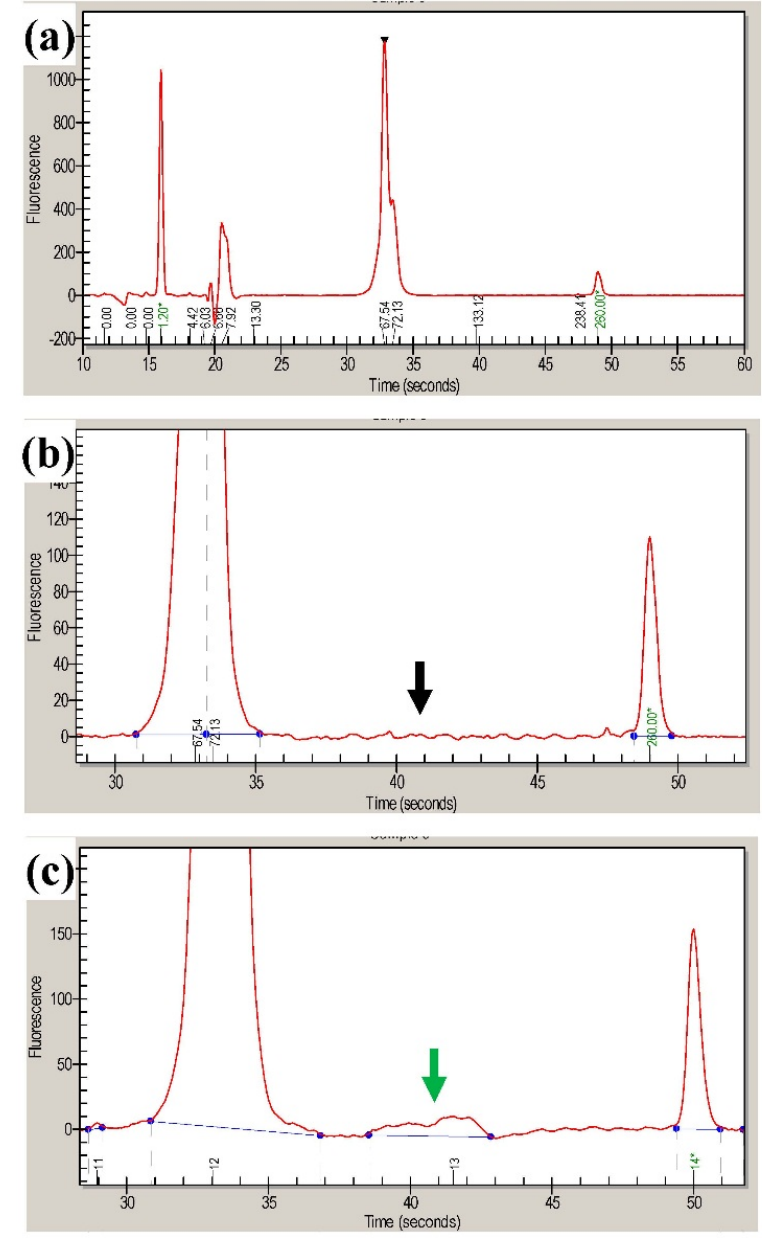

RCA120 preparation
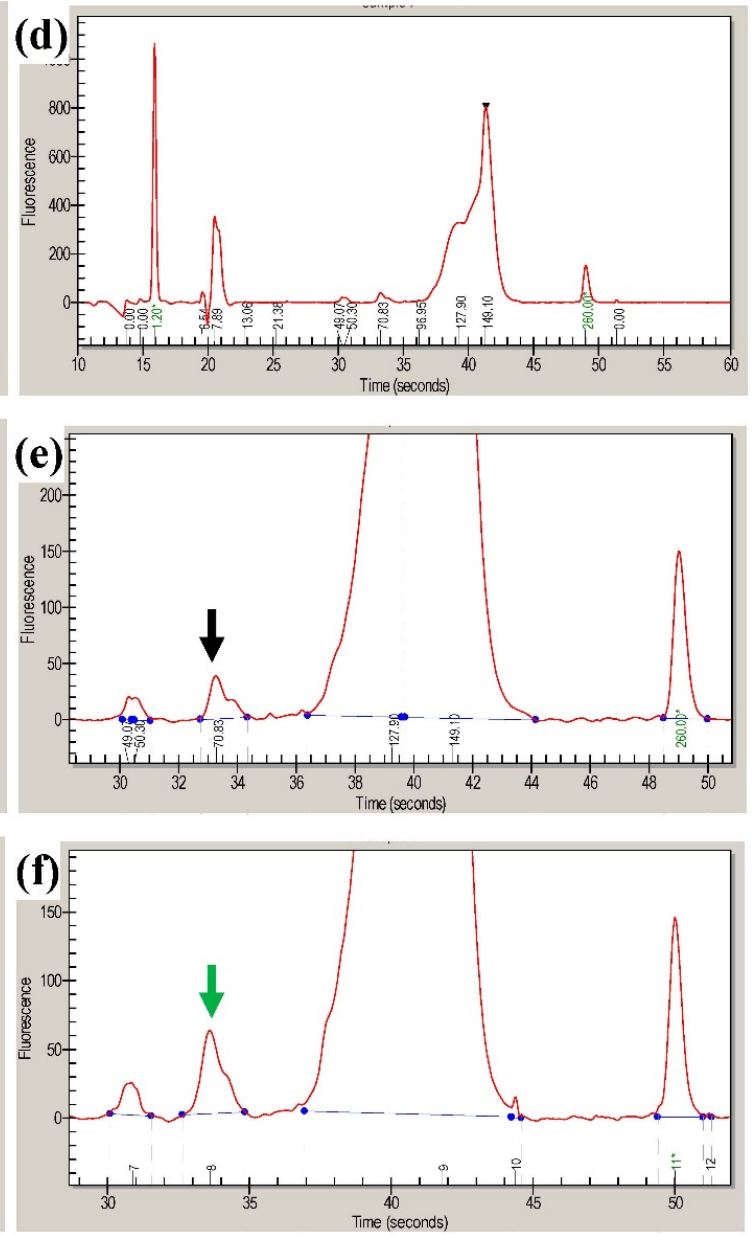

Figure 4. CGE analysis. Electropherogram of purified ricin $(\mathbf{a}-\mathbf{c})$ and purified RCA120 (d-f). For (a), the ricin preparation was diluted 1:1 and a ricin doublet peak at approximately $33 \mathrm{~s}$ was obtained; (b) expanded region around $40 \mathrm{~s}$ migration time where a signal of RCA120 would be expected (black arrow); (c) standard addition of $5 \%$ of RCA120 to the ricin preparation $(0.076 \mathrm{mg}$ of RCA120/mL), highlighted by a green arrow. For (d), the RCA120 preparation diluted 1:1 resulted in a broad peak indicating RCA120 at approximately $40 \mathrm{~s}$; (e) expanded electropherogram of (d) indicating a small peak at the migration time of ricin at $34 \mathrm{~s}$ (black arrow). The integrated peak area was equivalent to $1.8 \%$ relative to the RCA120 peak area. (f) Standard addition of $2 \%$ of ricin to the RCA120 preparation (0.02 $\mathrm{mg}$ of ricin/mL).

In the RCA120 preparation, a peak from RCA120 was obtained at 120-150 kDa and a minor peak at the migration time of ricin of around $33 \mathrm{~s}$ could be observed (black arrow). The concentration of ricin relative to the RCA120 in this preparation was estimated by the software to be $1.8 \%$ (Figure $4 \mathrm{~d}$,e). The result was confirmed by the addition of $2 \%$ of ricin relative to the RCA120 concentration. The peak attributed to ricin increased in size by a factor of approximately two (Figure 4f, green arrow).

\subsubsection{Molecular Weight by LC-ESI MS}

The molecular weight of the purified, intact ricin preparation was determined based on LC-ESI MS. The molecular weight was both calculated manually from the data as well as determined from deconvoluted mass spectra. The spectra obtained showed the heterogeneity in ricin due to a varying level of glycosylation (Figure 5). Based on previous experiments and literature data, the glycosylation pattern of the mass spectrum is indicative of the cultivar used for the isolation of ricin [27]. 


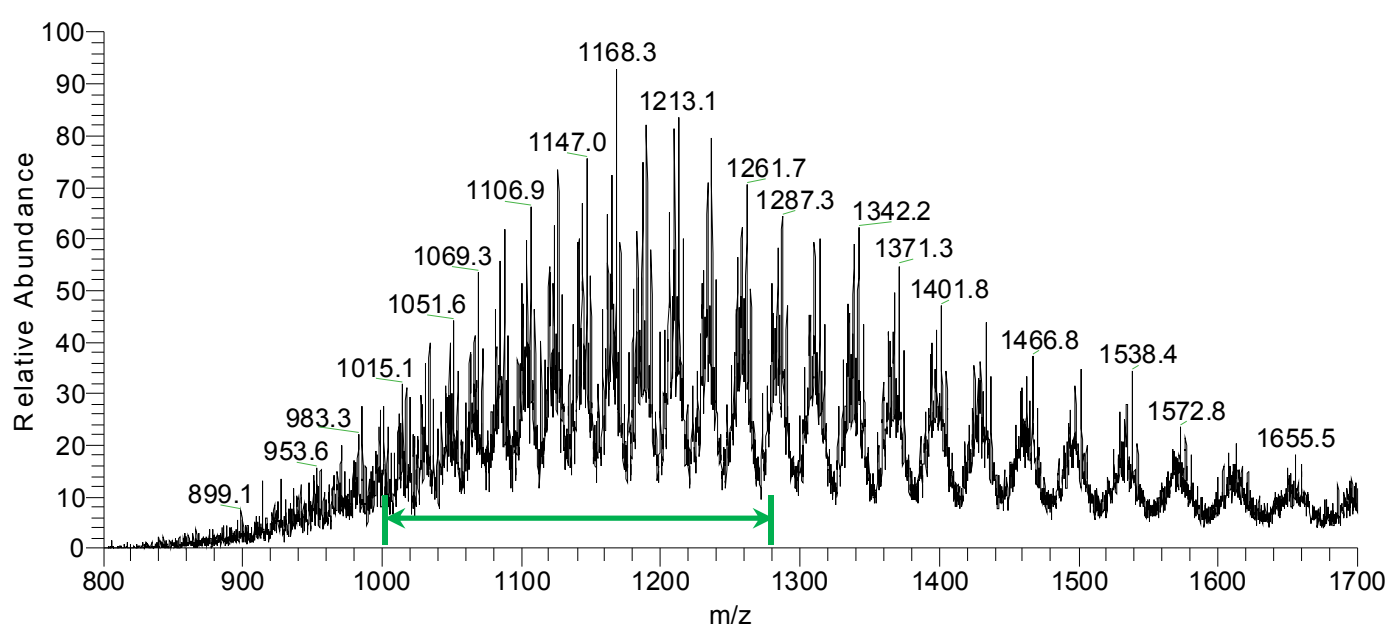

Figure 5. LC-ESI MS spectrum of purified ricin preparation. The highlighted range 1000-1280 $\mathrm{m} / \mathrm{z}$ indicated by a green arrow was used for manual molecular weight determination.

Adjacent peaks in the deconvoluted mass spectrum of the purified ricin in Figure 6 are separated by 162 mass units which correspond to different ricin glycoforms separated by the number of hexose units in the attached glycan structures. The molecular weight determined by the instrument software for the major glycoform was $63,034 \mathrm{Da}$. The manually calculated molecular weight using the peaks in the range indicated in Figure 5 was determined at $63,032 \pm 2 \mathrm{Da}$. This matches well the molecular weight of previously prepared ricin from the same cultivar (unpublished) and published information [27,53-55].

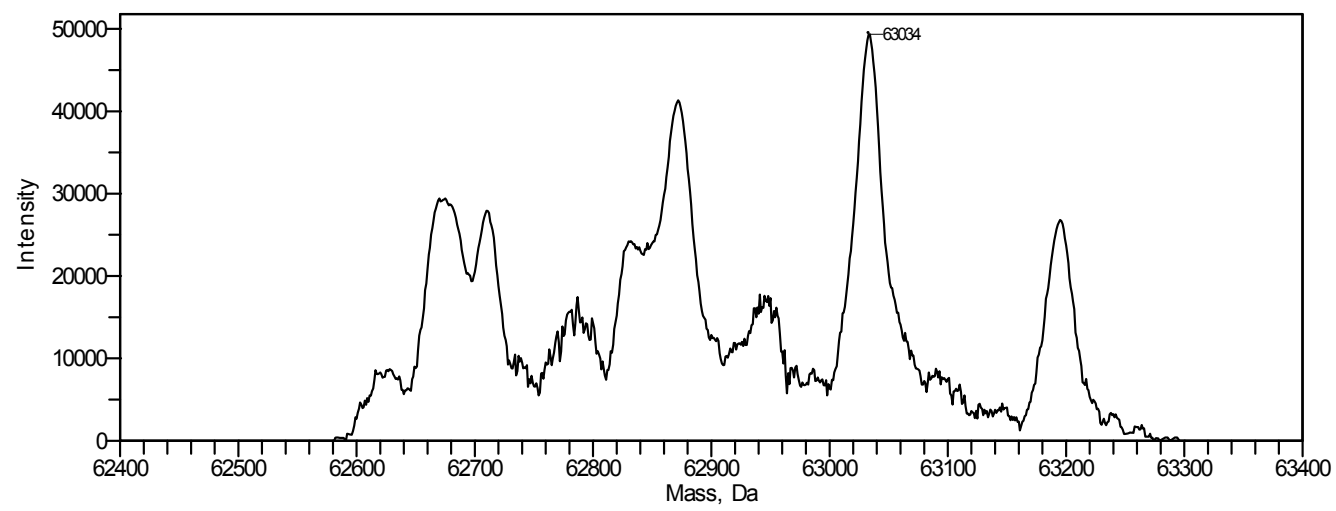

Figure 6. Deconvoluted mass spectrum of purified ricin preparation.

\subsection{Identification of Ricin and RCA120 and Analysis of Potential Trace Contaminants}

\subsubsection{Identification of Ricin and RCA120 by Tryptic Fingerprinting and Sequencing}

The aim of the LC-ESI MS/MS analysis (this section) and the MALDI-TOF MS/MS analysis (Section 2.2.2) was to unambiguously identify ricin and RCA120 in the protein preparations prepared from $R$. communis and to thoroughly check for potential cross-contaminations with other $R$. communis proteins. To this end, both preparations were reduced, alkylated, and underwent tryptic digestion. The tryptic fragments were analyzed and sequenced by LC-ESI MS/MS, focusing on identification of the isoforms of ricin $\mathrm{D}$, ricin $\mathrm{E}$, and their corresponding $\mathrm{A}$ and $\mathrm{B}$ chains, as well as RCA120. Figure 7 exemplarily shows the base peak chromatograms of the trypsin digests of ricin and RCA120 preparations obtained by LC-ESI MS/MS analysis. The peptides from ricin D observed in the ricin preparation covered $95 \%$ of the sequence of the A chain and $74 \%$ of the B chain. In the RCA120 
preparation, peptides representing $90 \%$ of the A chain and $79 \%$ of the B chain of RCA120 were detected. The full sequences of ricin D, ricin E, and RCA120 are displayed in Table 1. Sequences displayed in red show peptides which were experimentally detected by combining LC-ESI MS/MS and MALDI-TOF MS/MS data (this Section and Section 2.2.2).

(a)

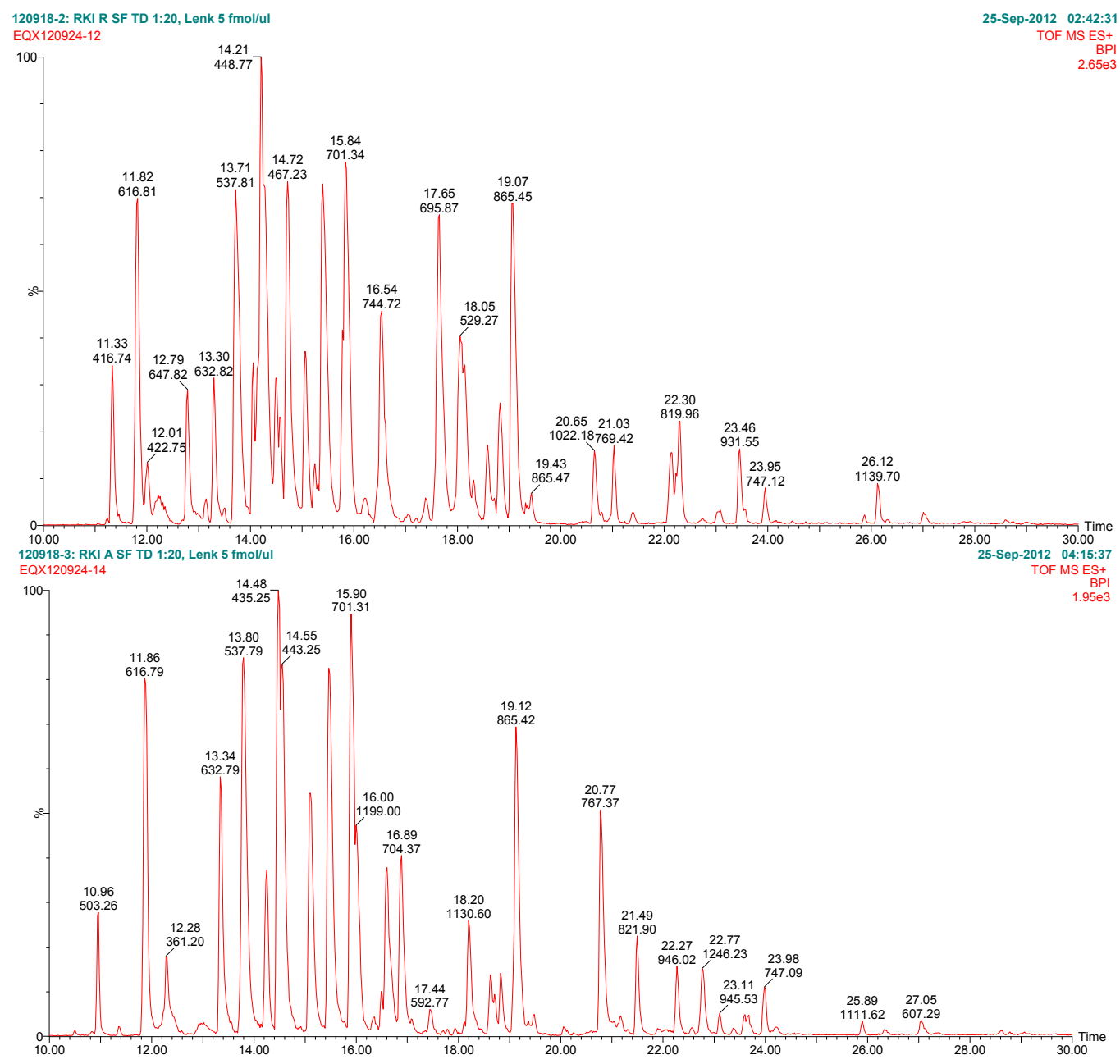

Figure 7. Base peak chromatograms of the trypsin digests of (a) purified ricin and (b) purified RCA120. The relative intensity is plotted against the retention time. Peaks are labeled with retention time and the $m / z$ value of the base peak.

Tables 2 and 3 list the theoretical trypsin digest peptides obtained from chains A and B of ricin D (Uniprot [56] ID: P02879), and those from chain B of ricin E (NCBI Genpept [57] ID: GI:225419) are found in Table 4.

The corresponding trypsin digest peptides from RCA120 (Uniprot [56] ID: P06750) and for chain B (NCBI Genpept [57] ID: GI:225114) are shown in Tables 5 and 6. In each of the tables, the molecular ions of the experimentally observed peptides are indicated by bold typeface. Also, the peptides that can be used to distinguish ricin D from ricin $\mathrm{E}$ and RCA120 from ricin D are indicated in bold typeface. 
Table 1. The amino acid sequences of ricin $D$, ricin $E$, and RCA120 identified in purified ricin and purified RCA120. The experimentally detected sequences using liquid chromatography-electrospray ionization-tandem mass spectrometry (LC-ESI MS/MS) and matrix-assisted laser desorption/ionization-time of flight tandem mass spectrometry (MALDI-TOF MS/MS) as trypsin digest peptides are indicated in red.

\begin{tabular}{cc}
\hline \multicolumn{2}{l}{ Sequence coverage of ricin preparation: } \\
\hline \multicolumn{1}{l}{ Ricin D chain A (Uniprot P02879, NCBI GI:132567) } \\
\hline 1 & IFPKQYPIIN FTTAGATVQS YTNFIRAVRG RLTTGADVRH EIPVLPNRVG LPINQRFILV \\
61 & ELSNHAELSV TLALDVTNAY VVGYRAGNSA YFFHPDNQED AEAITHLFTD VQNRYTFAFG \\
121 & GNYDRLEQLA GNLRENIELG NGPLEEAISA LYYYSTGGTQ LPTLARSFII CIQMISEAAR \\
181 & FQYIEGEMRT RIRYNRRSAP DPSVITLENS WGRLSTAIQE SNQGAFASPI QLQRRNGSKF \\
241 & SVYDVSILIP IIALMVYRCA PPPSSQF \\
\hline Ricin D chain B (Uniprot P02879, NCBI GI:132567) \\
\hline 1 & ADVCMDPEPI VRIVGRNGLC VDVRDGRFHN GNAIQLWPCK SNTDANQLWT LKRDNTIRSN \\
61 & GKCLTTYGYS PGVYVMIYDC NTAATDATRW QIWDNGTIIN PRSSLVLAAT SGNSGTTLTV \\
121 & QTNIYAVSQG WLPTNNTQPF VTTIVGLYGL CLQANSGQVW IEDCSSEKAE QQWALYADGS \\
181 & IRPQQNRDNC LTSDSNIRET VVKILSCGP ASSGQRWMFKN DGTILNLYSG LVLDVRASDP \\
241 & SLKQIILYPL HGDPNQIWLP LF \\
\hline Ricin E chain B (NCBI GI:225419) \\
\hline 1 & ADVCMDPEPI VRIVGRNGLC VDVRDGRFHN GNAIQLWPCK SNTDANQLWT LKRDNTIRSN \\
61 & GKCLTTYGYP SGVYVMIYDC NTAATDATRW QIWDNGTIIN PRSSLVLAAT SGNSGTTLTV \\
121 & QTNIYAVSQG WLPTNNTQPF VTTIVGLYGM CLQANSGKVW LEDCTSEKAE QQWALYADGS \\
181 & IRPQQNRDNC LTTDANIKGT VVKILSCGPA SSGQRWMFKN DGTILNLYNG LVLDVRRSDP \\
241 & SLKQIIVHPV HGNLNQIWLP LF \\
\hline Sequence coverage of RCA120 preparation: \\
\hline RCA120 chain A (Uniprot P06750, NCBI GI:113504) \\
\hline 1 & IFPKQYPIIN FTTADATVES YTNFIRAVRS HLTTGADVRH EIPVLPNRVG LPISQRFILV \\
61 & ELSNHAELSV TLALDVTNAY VVGCRAGNSA YFFHPDNQED AEAITHLFTD VQNSFTFAFG \\
121 & GNYDRLEQLG GLRENIELGT GPLEDAISAL YYYSTCGTQI PTLARSFMVC IQMISEAARF \\
181 & QYIEGEMRTR IRYNRRSAPD PSVITLENSW GRLSTAIQES NQGAFASPIQ LQRRNGSKFN \\
241 & VYDVSILIPI IALMVYRCAP PPSSQF \\
\hline RCA120 chain B (NCBI GI:225114) \\
\hline 1 & ADVCMDPEPI VRIVGRNGLC VDVFGEEFTD GNPIQLWPCK SNTDWNQLWT LRKDSTIRSD \\
61 & GKCLTISKSS PGQQVVIYNC STATVGATRW QIWDNRTIIN PTSGLVLAAT SGNSGTKLTV \\
121 & QTNIYAVSQG WLPTNNTQPF VTTIVGLYGM CLQANSGKVW LEDCTSEKAE QQWALYADGS \\
181 & IRPQQNRDNC LTTDANIKGT VVKILSCGPA SSGQRWMFKN DGTILNLYNG LVLDVRRSDP \\
241 & SLKQIIVHPV HGNLNQIWLP LF \\
\hline
\end{tabular}

Table 2. Ricin D and E chain A trypsin digest peptides (Uniprot [56] ID: P02879, NCBI Genpept [57] ID: GI:132567), reduced and carbamidomethylated. Ricin/RCA120-distinguishing peptides and observed molecular ions are given in bold.

\begin{tabular}{|c|c|c|c|c|c|}
\hline $\mathrm{T} \#$ (a) & Amino Acid Sequence & $(\mathrm{M}+\mathrm{H})^{+}$ & $(\mathrm{M}+2 \mathrm{H})^{2+}$ & $(\mathrm{M}+3 \mathrm{H})^{3+}$ & $(\mathrm{M}+4 \mathrm{H})^{4+}$ \\
\hline T1a & IFPK & 504.3180 & - & - & - \\
\hline T2a-glyc & QYPIINFTTAGATVQSYTNFIR & $3675.6946^{*}$ & $1838.3509^{*}$ & $1225.9031^{*}$ & $919.6791^{*}$ \\
\hline T3a & AVR & 345.2245 & - & - & - \\
\hline T4a & GR & 232.1404 & - & - & - \\
\hline T5a & LTTGADVR & 832.4523 & 416.7298 & - & - \\
\hline T6a & HEIPVLPNR & 1074.6054 & 537.8063 & - & - \\
\hline T7a & VGLPINQR & 896.5312 & 448.7692 & - & - \\
\hline T8a & FILVELSNNHAELSVTLALDVTNAYVVGYR & 3206.7095 & 1603.8584 & 1069.5747 & 802.4328 \\
\hline T9a & AGNSAYFFHPDNQEDAEAITHLFTDVQNR & 3307.5038 & 1654.2555 & 1103.1728 & 827.6314 \\
\hline T10a & YTFAFGGNYDR & 1310.5800 & 655.7936 & - & - \\
\hline T11a & LEQLAGNLR & 1013.5738 & 507.2905 & - & - \\
\hline T12a & ENIELGNGPLEEAISALYYYSTGGTQLPTLAR & 3440.7219 & 1720.8646 & 1147.5788 & 860.9359 \\
\hline T13a & SFIICIQMISEAAR & 1638.8342 & 819.9207 & - & - \\
\hline $\mathrm{T} 14 \mathrm{a}$ & FQYIEGEMR & 1172.5404 & 586.7738 & - & - \\
\hline $\mathrm{T} 15 \mathrm{a}$ & $\widehat{T R}$ & 276.1666 & - & - & - \\
\hline $\mathrm{T} 16 \mathrm{a}$ & IR & 288.2030 & - & - & - \\
\hline $\mathrm{T} 17 \mathrm{a}$ & YNR & 452.2252 & - & - & - \\
\hline $\mathrm{T} 18 \mathrm{a}$ & $\mathrm{R}$ & 175.1189 & - & - & - \\
\hline T19a & SAPDPSVITLENSWGR & 1728.8551 & 864.9312 & - & - \\
\hline $\mathrm{T} 20 \mathrm{a}$ & LSTAIQESNQGAFASPIQLQR & 2259.1727 & 1130.0900 & 753.7291 & - \\
\hline $\mathrm{T} 21 \mathrm{a}$ & $\mathrm{R}$ & 175.1189 & - & - & - \\
\hline $\mathrm{T} 22 \mathrm{a}$ & NGSK & 405.2092 & - & - & - \\
\hline T23a & FSVYDVSILIPIIALMVYR & 2212.2450 & 1106.6261 & 738.0865 & - \\
\hline $\mathrm{T} 24 \mathrm{a}$ & CAPPPSSQF & 990.4349 & 495.7211 & - & - \\
\hline
\end{tabular}

(a) Trypsin digest peptides numbered from the amino terminal of the polypeptide chain. ${ }^{*}$ Main glycopeptide. 
Table 3. Ricin D chain B trypsin digest peptides (Uniprot [56] ID: P02879, NCBI Genpept [57] ID: GI:132567), reduced and carbamidomethylated. Ricin/RCA120 distinguishing peptides and observed molecular ions are given in bold.

\begin{tabular}{|c|c|c|c|c|c|}
\hline $\mathrm{T} \#$ (a) & Amino Acid Sequence & $(\mathrm{M}+\mathrm{H})^{+}$ & $(\mathrm{M}+2 \mathrm{H})^{2+}$ & $(\mathrm{M}+3 \mathrm{H})^{3+}$ & $(\mathrm{M}+4 \mathrm{H})^{4+}$ \\
\hline T1b & ADVCMDPEPIVR & 1401.6501 & 701.3287 & - & - \\
\hline $\mathrm{T} 2 \mathrm{~b}$ & IVGR & 444.2929 & - & _ & ـ \\
\hline T3b & NGLCVDVR & 932.4618 & 466.7345 & - & - \\
\hline $\mathrm{T} 4 \mathrm{~b}$ & DGR & 347.1673 & - & - & - \\
\hline $\mathbf{T} 5 \mathbf{b}$ & FHNGNAIQLWPCK & 1584.7740 & 792.8906 & - & ـ \\
\hline T6b & SNTDANQẼWTLK & 1390.6961 & 695.8517 & - & - \\
\hline $\mathrm{T} 7 \mathrm{~b}$ & $\mathrm{R}$ & 175.1189 & - & - & - \\
\hline $\mathrm{T} 8 \mathrm{~b}$ & DNTIR & 618.3205 & - & - & - \\
\hline T9b & SNGK & 405.2092 & - & - & - \\
\hline T10b & CLTTYGYSPGVYVMIYDCNTAATDATR & 3063.3532 & 1532.1802 & 1021.7893 & 766.5938 \\
\hline T11b-glyc & WQIWDNGTIINPR & $2991.2987^{*}$ & $1496.1530^{*}$ & $997.7711 *$ & $748.5801^{*}$ \\
\hline T12b-glyc & $\begin{array}{l}\text { SSLVLAATSGNSGTTLTVQTNIYAVSQGWLPTNN } \\
\text { TOPFVTTIVGLYGLCLOANSGOVWIEDCSSEK }\end{array}$ & [7047.4666] & - & - & - \\
\hline $\mathrm{T} 13 \mathrm{~b}$ & AEQQWALYADGSIRPQQNR & 2231.0952 & 1116.0512 & 744.3699 & - \\
\hline T14b & DNCLTSDSNIR & 1294.5692 & 647.7882 & - & - \\
\hline T15b & ETVVK & 575.3399 & - & - & - \\
\hline T16b & ILSCGPASSGQR & 1232.6052 & 616.8062 & - & - \\
\hline $\mathrm{T} 17 \mathrm{~b}$ & WMFK & 611.3010 & 306.1541 & - & - \\
\hline T18b & NDGTILNLYSGLVLDVR & 1862.0018 & 931.5045 & - & - \\
\hline T19b & ASDPSLK & 717.3777 & 359.1925 & - & - \\
\hline T20b & QIILYPLHGDPNQIWLPLF & 2277.2430 & 1139.1251 & 759.7525 & - \\
\hline
\end{tabular}

(a) Trypsin digest peptides numbered from the amino terminal of the polypeptide chain. * Main glycopeptide.

Table 4. Ricin E chain B trypsin digest peptides (NCBI Genpept [57] ID: GI:225419), reduced and carbamidomethylated. Ricin D/E-distinguishing sequence and observed molecular ions are given in bold.

\begin{tabular}{|c|c|c|c|c|c|}
\hline $\mathrm{T} \#{ }^{(a)}$ & Amino Acid Sequence & $(\mathrm{M}+\mathrm{H})^{+}$ & $(\mathrm{M}+2 \mathrm{H})^{2+}$ & $(\mathrm{M}+3 \mathrm{H})^{3+}$ & $(\mathrm{M}+4 \mathrm{H})^{4+}$ \\
\hline $\mathrm{T} 1 \mathrm{~b}$ & ADVCMDPEPIVR & 1401.6501 & 701.3287 & - & - \\
\hline $\mathrm{T} 2 \mathrm{~b}$ & IVGR & 444.2929 & - & - & - \\
\hline $\mathrm{T} 3 \mathrm{~b}$ & NGLCVDVR & 932.4618 & 466.7345 & - & - \\
\hline $\mathrm{T} 4 \mathrm{~b}$ & DGR & 347.1673 & - & - & - \\
\hline $\mathrm{T} 5 \mathrm{~b}$ & FHNGNAIQLWPCK & 1584.7740 & 792.8906 & - & - \\
\hline T6b & SNTDANQLWTLK & 1390.6961 & 695.8517 & - & - \\
\hline $\mathrm{T} 7 \mathrm{~b}$ & $\mathrm{R}$ & 175.1189 & - & - & - \\
\hline $\mathrm{T} 8 \mathrm{~b}$ & DNTIR & 618.3205 & - & - & - \\
\hline $\mathrm{T} 9 \mathrm{~b}$ & SNGK & 405.2092 & - & - & - \\
\hline T10b & CLTTYGYPSGVYVMIYDCNTAATDATR & 3063.3532 & 1532.1802 & 1021.7893 & 766.5938 \\
\hline T11b glyc & WQIWDNGTIINPR & - & $1496.1530^{*}$ & $997.7711^{*}$ & $748.5801^{*}$ \\
\hline T12b glyc & $\begin{array}{l}\text { SSLVLAATSGNSGTTLTVQTNIYAVSQGWL } \\
\text { PTNNTQPFVTTIVGLYGMCLQANSGK }\end{array}$ & [5831.9258] & 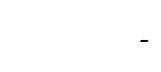 & - & 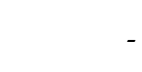 \\
\hline T13b & VWLEDCTSEK & 1266.5670 & 633.7871 & - & - \\
\hline $\mathrm{T} 14 \mathrm{~b}$ & AEQQWALYADGSIRPQQNR & 2231.0952 & 1116.0512 & 744.3699 & - \\
\hline T15b & DNCLTTDANIK & 1264.5838 & 632.7955 & - & - \\
\hline T16b & GTVVK & 503.3187 & - & - & - \\
\hline $\mathrm{T} 17 \mathrm{~b}$ & ILSCGPASSGQR & 1232.6052 & 616.8062 & - & - \\
\hline $\mathrm{T} 18 \mathrm{~b}$ & WMFK & 611.3010 & 306.1541 & - & - \\
\hline T19b & NDGTILNLYNGLVLDVR & 1889.0127 & 945.0100 & - & - \\
\hline T20b & $\mathrm{R}$ & 175.1189 & - & - & - \\
\hline T21b & SDPSLK & 646.3406 & 323.6739 & - & - \\
\hline $\mathrm{T} 22 \mathrm{~b}$ & QIIVHPVHGNLNQIWLPLF & 2238.2545 & 1119.6309 & 746.7564 & - \\
\hline
\end{tabular}

(a) Trypsin digest peptides numbered from the amino terminal of the polypeptide chain. ${ }^{*}$ Main glycopeptide. 
Table 5. RCA120 chain A (Uniprot [56] ID: P06750, NCBI Genpept [57] ID: GI:113504) trypsin digest peptides, reduced and carbamidomethylated. Ricin/RCA120-distinguishing peptides and observed molecular ions are given in bold.

\begin{tabular}{|c|c|c|c|c|c|}
\hline $\mathrm{T} \#{ }^{(\mathbf{a})}$ & Amino Acid Sequence & $(\mathrm{M}+\mathrm{H})^{+}$ & $(\mathrm{M}+2 \mathrm{H})^{2+}$ & $(\mathrm{M}+3 \mathrm{H})^{3+}$ & $(\mathrm{M}+4 \mathrm{H})^{4+}$ \\
\hline T1a & IFPK & 504.3180 & - & - & - \\
\hline T2a glyc & QYPIINFTTADATVESYTNFIR & $3734.6841^{*}$ & $1867.8457^{*}$ & $1245.5662 *$ & $934.4265^{*}$ \\
\hline T3a & AVR & 345.2245 & - & - & - \\
\hline T4a & SHLTTGADVR & 1056.5432 & 528.7752 & - & - \\
\hline T5a & HEIPVLPNR & 1074.6054 & 537.8063 & - & - \\
\hline T6a & VGLPISQR & 869.5203 & 435.2638 & - & - \\
\hline T7a & FILVELSNHAELSVTLALDVTNAYVVGCR & 3203.6768 & 1602.3420 & 1068.5638 & 801.6747 \\
\hline T8a & $\begin{array}{l}\text { AGNSAYFFHPDNQEDAEAIT } \\
\text { LFTDVQNSFTFAFGGNYDR }\end{array}$ & 4514.0020 & 2257.5046 & 1505.3389 & 1129.2560 \\
\hline T9a & LEQLGGLR & 885.5152 & 443.2612 & - & - \\
\hline T10a & ENIELGTGPLEDAISALYYYSTCGTQIPTLAR & 3516.7202 & 1758.8637 & 1172.9116 & 879.9355 \\
\hline T11a & SFMVCIQMISEAAR & 1642.7750 & 821.8911 & - & - \\
\hline $\mathrm{T} 12 \mathrm{a}$ & FQYIEGEMR & 1172.5404 & 586.7738 & - & - \\
\hline $\mathrm{T} 13 \mathrm{a}$ & TR & 276.1666 & - & - & - \\
\hline T14a & IR & 288.2030 & - & - & - \\
\hline T15a & YNR & 452.2252 & - & - & - \\
\hline T16a & $\mathrm{R}$ & 175.1189 & - & - & - \\
\hline T17a & SAPDPSVITLENSWGR & 1728.8551 & 864.9312 & - & - \\
\hline T18a & LSTAIQESNQGAFASPIQLQ R & 2259.1727 & 1130.0900 & 753.7291 & - \\
\hline $\mathrm{T} 19 \mathrm{a}$ & $\mathrm{R}$ & 175.1189 & - & - & - \\
\hline $\mathrm{T} 20 \mathrm{a}$ & NGSK & 405.2092 & - & - & - \\
\hline T21a & FNVYDVSILIPIIALMVYR & 2239.2559 & 1120.1316 & 747.0902 & - \\
\hline $\mathrm{T} 22 \mathrm{a}$ & CAPPPSSQF & 990.4349 & 495.7211 & - & - \\
\hline
\end{tabular}

Table 6. RCA120 chain B (NCBI Genpept [57] ID: GI:225114) trypsin digest peptides, reduced and carbamidomethylated. Ricin/RCA120-distinguishing peptides and observed molecular ions are given in bold.

\begin{tabular}{|c|c|c|c|c|c|}
\hline $\mathrm{T} \#{ }^{(a)}$ & Amino Acid Sequence & $(\mathrm{M}+\mathrm{H})^{+}$ & $(\mathrm{M}+2 \mathrm{H})^{2+}$ & $(\mathrm{M}+3 \mathrm{H})^{3+}$ & $(\mathrm{M}+4 \mathrm{H})^{4+}$ \\
\hline T1b & ADVCMDPEPIVR & 1401.6501 & 701.3287 & - & - \\
\hline $\mathrm{T} 2 \mathrm{~b}$ & IVGR & 444.2929 & - & - & - \\
\hline T3b & NGLCVDVFGEEFTDGNPIQLWPCK & 2795.2803 & 1398.1438 & 932.4316 & 699.5755 \\
\hline T4b & SNTDWNQLWTLR & 1533.7444 & 767.3758 & - & - \\
\hline $\mathrm{T} 5 \mathrm{~b}$ & K & 147.1128 & - & - & - \\
\hline T6b & DSTIR & 591.3096 & - & - & - \\
\hline $\mathrm{T} 7 \mathrm{~b}$ & SDGK & 406.1932 & - & - & - \\
\hline T8b & CLTISK & 721.3913 & 361.1993 & - & - \\
\hline T9b glyc & SSPGQQVVIYNCSTATVGATR & $3366.4960^{*}$ & $1683.7516^{*}$ & $1122.8369^{*}$ & $842.3795^{*}$ \\
\hline T10b-glyc & WQIWDNR & $2395.9657^{*}$ & $1198.4865^{*}$ & $799.3268^{*}$ & \\
\hline T11b & TIINPTSGLVLAATSGNSGTK & 2002.0815 & 1001.5444 & 668.0320 & - \\
\hline T12b glyc & $\begin{array}{l}\text { LTVQTNIYAVSQGWLPTNNTQPFVTTIVG } \\
\text { LYGMCLQANSGK }\end{array}$ & [4485.2581] & - & - & - \\
\hline $\mathrm{T} 13 \mathrm{~b}$ & VWLEDCTSEK & 1266.5670 & 633.7871 & - & \\
\hline T14b & AEQQWALYADGSIRPQQNR & 2231.0952 & 1116.0512 & 744.3699 & - \\
\hline $\mathrm{T} 15 \mathrm{~b}$ & DNCLTTDANIK & 1264.5838 & 632.7955 & - & - \\
\hline T16b & GTVVK & 503.3187 & - & - & - \\
\hline $\mathrm{T} 17 \mathrm{~b}$ & ILSCGPASSGQR & 1232.6052 & 616.8062 & - & - \\
\hline $\mathrm{T} 18 \mathrm{~b}$ & WMFK & 611.3010 & 306.1541 & - & - \\
\hline $\mathrm{T} 19 \mathrm{~b}$ & NDGTILNLYNGLVLDVR & 1889.0127 & 945.0100 & - & - \\
\hline $\mathrm{T} 20 \mathrm{~b}$ & $\mathrm{R}$ & 175.1189 & - & - & - \\
\hline $\mathrm{T} 21 \mathrm{~b}$ & SDPSLK & 646.3406 & 323.6739 & - & - \\
\hline $\mathrm{T} 22 \mathrm{~b}$ & QIIVHPVHGNLNQIWLPLF & 2238.2545 & 1119.6309 & 746.7564 & - \\
\hline
\end{tabular}

(a) Trypsin digest peptides numbered from the amino terminal of the polypeptide chain. * Main glycopeptide.

In the $\mathrm{E}$ isoform of ricin, the amino acid sequence of chain $\mathrm{A}$ is identical to that of ricin $\mathrm{D}$. The differences between $\mathrm{D}$ and $\mathrm{E}$ are located at the $\mathrm{B}$ chain, where approximately half the chain at the 
carboxyl terminal end has the same amino acid sequence as RCA120. In the R. communis cultivar used here, both ricin isoforms were found. Several peptides detected in the purified ricin preparation were attributed to ricin E, e.g., T13b, T15b, T19b, and T22b (Table 4).

Besides the sequence GI:225419 [17], two other sequences for ricin E, GI:2169612 and GI:225896 [18], are published in the NCBI Genpept database (The National Center for Biotechnology Information, National Library of Medicine, Bethesda, MD, USA) [57]. The peptide molecular ions at $616^{2+}$ and $746^{3+}$ matched T17b and T22b of GI:225419 and distinguished it from the other ricin E sequences (GI:225896, GI:2169612).

The ricin E sequence GI:225419 has a Pro-Ser at position 70-71 [17] identical to that published for ricin D by the same group [58,59]. Pro70-Ser71 in the T10b peptide from this ricin preparation could not be confirmed (see Supplementary Information, Figure S1). Instead, data supported Ser-Pro at position 70-71, which corresponds to other sequences published for ricin E (GI:225896 [18], GI:2169612) and ricin D (GI:132567 [60]). The discrepancy could be due to an actual difference between isoforms or flaws in the older data using sequencing methods available at that time. A comparison to X-ray structures could not be performed, since no structure for the B chain of ricin $\mathrm{E}$ is available so far.

The NCBI database contains a number of sequence variants for the B chain of RCA120, where sequence GI:225114 differs from other RCA120 sequences, e.g. Uniprot P06750 (NCBI Genpept GI:113504; X-ray structure: 1RZO). In the purified RCA120 preparation, the two peptides identified as T9 glycopeptide and T11 of the RCA120 chain B sequence GI:225114 distinguished this isoform from other RCA120 sequences, e.g., GI:113504 (Table 6; Supplementary Information Figures S2 and S3). The product ion spectrum of the T3 peptide of chain B, however, was consistent with the amino acid sequence of GI:113504 and not GI:225114 (Supplementary Information Figure S4). Again, this inconsistency could be due to lower reliability of older sequencing methods.

Twenty-eight peptides from ricin and 27 from RCA120 were detected by the nano-LC-MS method used in this investigation. Nineteen of the ricin peptides were proteotypic, i.e., not found in other proteins including RCA120. For further in-depth characterization, increased sequence coverage could be obtained on sections resistant to trypsin by using proteases with alternative cleavage specificity, e.g., chymotrypsin or pepsin.

For identification and quantification, sequence coverage is less important, and instrument capacity and sensitivity requirements might restrict the number of monitored peptides. Peptides suitable for identification and quantification of ricin, i.e., proteotypic and detected at high intensity, are consistent with those proposed earlier $[44,61,62]$ with the exception of T19b, which is polar and was not retained by the trapping column in the nano-LC system used here. Diagnostic peptides for ricin with high identification potential observed here were $\mathrm{T} 5, \mathrm{~T} 7, \mathrm{~T} 9, \mathrm{~T} 10$, and $\mathrm{T} 11$ from the A chain and T6, T11, T18, and T20 from the B chain. When the sample was reduced and alkylated before digestion, both T13 from chain A and T14 from chain B (ricin D) also exhibited good electrospray response and excellent MS/MS sequence information. B chain peptides T3 and T5 were both prone to deamidation, which made them less suitable as target peptides for quantification and unequivocal identification.

In RCA120 T6 and T9 from chain A together with T4 from chain B were conserved in all isoforms and should be selected as primary target peptides for unequivocal identification of RCA120 as well as T11a when the sample is reduced and alkylated. Ricin E could be distinguished from ricin D by the B chain peptides highlighted in Table 4, primarily T13, T15, T19, and T22.

Peptides common to ricin and RCA120 suitable for detection and identification of both proteins when combined with proteotypic peptides were T6, T14, T19, and T20 from chain A and T13 and T16 from chain B of ricin. The disulfide linked peptide connecting the A and B chains in ricin and RCA120 had a relatively low electrospray response, but in samples at toxicologically relevant concentrations it was useful as an indication of potentially active toxin. 
When matched to the NCBIdatabase, the majority of the diagnostic ricin peptides were unique, except for T5a which was found in a Pomacea flagellata hemagglutinin (a freshwater snail) and B chain T3 which appeared in related ribosome-inactivating proteins [44]. The glycopeptide T11b also matched Viscum album lectin 1 (viscumin) and T19b three other proteins. As the databases continue to grow, overlaps with both functionally related and purely coincidental new proteins could occur.

Depending on the scenario, the number of peptides required for identification and their sequence coverage need to be considered. In contrast to recommendations for proteomic identification of unknown proteins in complex mixtures in the life sciences [63-65], the identification of target proteins in public health and forensic investigations involves the comparison of experimental data with authentic reference standards. Criteria for chromatographic retention time and ion ratios as well as the mass of digestion products and MS/MS sequence information will need to be specified [66].

The World Anti-Doping Agency (WADA) has published detailed identification criteria for proteins. Reporting of a unique amino acid sequence and minimum sequence coverage of $10 \%$ was specified [67]. Identification criteria for ricin in the context of verification of the Chemical Weapons Convention was proposed by a working group under the OPCW Scientific Advisory Board [68]. The MS criteria recommended reporting a minimum of two peptides from each of the chains with detailed experimental data and, furthermore, that the uniqueness of the peptides needs to be specified. Supporting data from immunological techniques, ricin functionality assay, molecular weight determination or PCR was additionally required for unambiguous identification.

Generally, no peptides from other $R$. communis components were detected in the trypsin digests of purified ricin and purified RCA120, e.g., 2S-albumin or the peptide biomarkers RCB-1 to -3 [69]. The next step was to analyze potential cross-contaminations of RCA120 in the purified ricin preparation and, vice versa, ricin in the purified RCA120 preparation. The concentration of the impurities in the preparations was calculated using the protein concentrations obtained from $\mathrm{UV}_{280}$ measurement and the responses of peptides specific for ricin and RCA120.

The amount of RCA120 in the purified ricin sample was calculated from the peak areas determined from the extracted ion chromatograms, using the RCA120 preparation as the analytical standard. Similarly, the amount of ricin in purified RCA120 was determined using the ricin preparation as the analytical standard. Based on this procedure, the amount of RCA120 in the ricin preparation was $1.4 \% \pm 0.4 \%$ relative to ricin based on the average of chain A peptides, and $4.5 \% \pm 1.5 \%$ based on chain B peptides. Therefore, the purity of ricin was specified to $\geqslant 97 \%$ based on the average of chain A and B peptides.

For the $R$. communis agglutinin preparation, the amount of ricin found was $0.5 \% \pm 0.2 \%$ calculated for chain A peptides and $1.4 \% \pm 0.7 \%$ for chain B peptides, resulting in an average purity of $>99 \%$. For both protein preparations, these results were in good agreement with the purity estimated from CGE analysis.

Overall, the purity of the ricin and the RCA120 preparation characterized in this work was very good. While for a commercial preparation of ricin a similar purity of $96 \%$ was reported, the corresponding RCA120 preparation showed a purity of only 68\% [43]. Additionally, our toxin preparations were derived from a defined $R$. communis cultivar, while the cultivar used for purification concerning the commercial products is not known.

As described above, the concentration of RCA120 in the purified ricin sample was consistently higher when calculated using chain B peptides than peptides from chain A. The same observation was made for ricin in the purified RCA120 sample. This was unexpected, considering the nature of the sample and the purification scheme used. The purification process consisted of an acid extraction at $\mathrm{pH} 4$ and ammonium sulfate precipitation of proteins. Affinity separation using a lactosyl-Sepharose-4B column was performed to isolate ricin and RCA120 from other constituents in the precipitate. Finally, size exclusion chromatography was used to separate ricin from RCA120. A possible explanation for the excess of chain B peptides over chain A peptides measured as contamination in both preparations could be a decomposition process or a reduction of the A-B 
interchain disulfide bond during the extraction and precipitation process. Chain B of both ricin and RCA120 would be isolated together with the intact proteins in the affinity step and could end up in the ricin size exclusion chromatography fraction to an extent depending on the size exclusion separation efficiency.

The amount of ricin $\mathrm{E}$ was determined in the ricin preparation using the chain $\mathrm{B}$ peptides that distinguish the E isoform from ricin D (Table 4). However, since they are shared with RCA120, the result had to be corrected by the content of RCA120 which can be determined from the intensity of the relevant RCA120 peptides, e.g., T6, T9, and T11 from chain A and T3 and T4 from chain B. Based on this procedure, the ratio of ricin $\mathrm{D}$ to ricin $\mathrm{E}$ was estimated to be close to one for the ricin preparation purified from $R$. communis carmencita in this work (data not shown).

\subsubsection{Analysis of Trace Contaminants by MALDI-TOF MS/MS Analysis}

The aim of the following experiments was to identify any impurities which might be present in both the ricin and the RCA120 preparation. As described in Section 2.1.1, the separation of larger amounts of both purified proteins by SDS-PAGE resulted in a number of faint lower-molecular-weight protein bands of unknown identity (Figure 2). It has remained unclear from the experiments conducted so far whether these protein bands were fragmented ricin or RCA120 proteins or irrelevant contaminants co-purified from the seeds. Therefore, both purified preparations were separated on an SDS-PAGE, and Coomassie-stained bands were cut out, and proteins were reduced, alkylated, and digested with trypsin, followed by a MALDI-TOF MS/MS analysis.

Figure 8 shows the Coomassie-stained gel which was used to cut out protein bands. The gel pieces corresponding to the individual protein bands were numbered sequentially R1 through R5 for the purified ricin preparation and A1 through A8 for the purified RCA120 preparation.

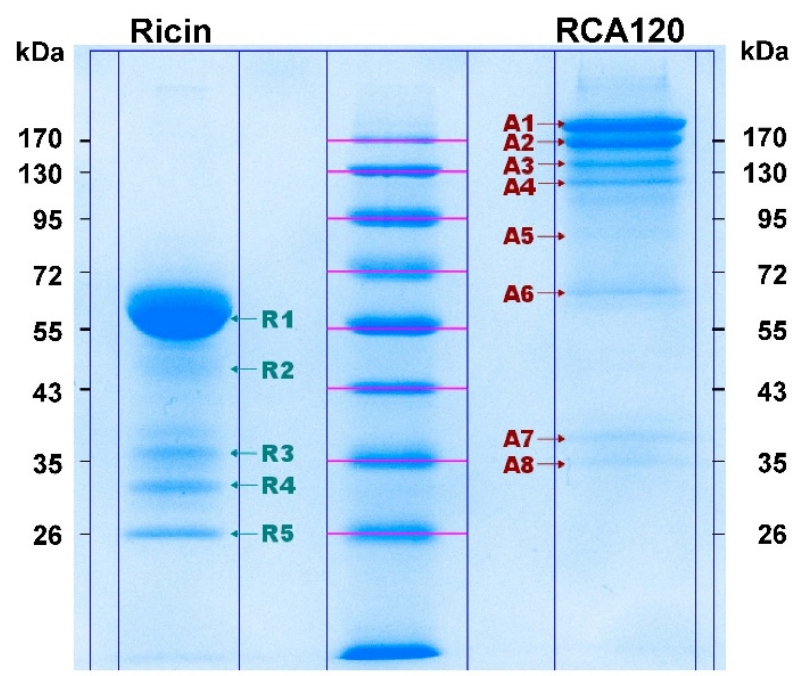

Figure 8. Separation of purified ricin and RCA120 by gel electrophoresis for subsequent MALDI-TOF MS/MS analysis. Purified ricin $(15.1 \mu \mathrm{g}$, left) or purified RCA120 (10.3 $\mu \mathrm{g}$, right) were separated on a 10\% SDS-PAGE. The indicated protein bands were cut out for further analysis: bands R1 through $\mathrm{R} 5$ for ricin and bands A1 through A8 for RCA120, respectively. For an in-gel digest, bands were cut out, reduced, and alkylated, used for tryptic digestion, and finally eluted from the gel, followed by MALDI-TOF MS/MS analysis.

Figure 9 shows an overview of resulting mass spectra of trypsin-digested ricin and RCA120 bands. All ricin bands showed similar mass spectral patterns, except for band 2, presumably because of a lower protein amount. For the purified RCA120 preparation, all mass spectra were similar, except for bands 5 and 8 , again presumably because of low protein amounts analyzed. 
(a)

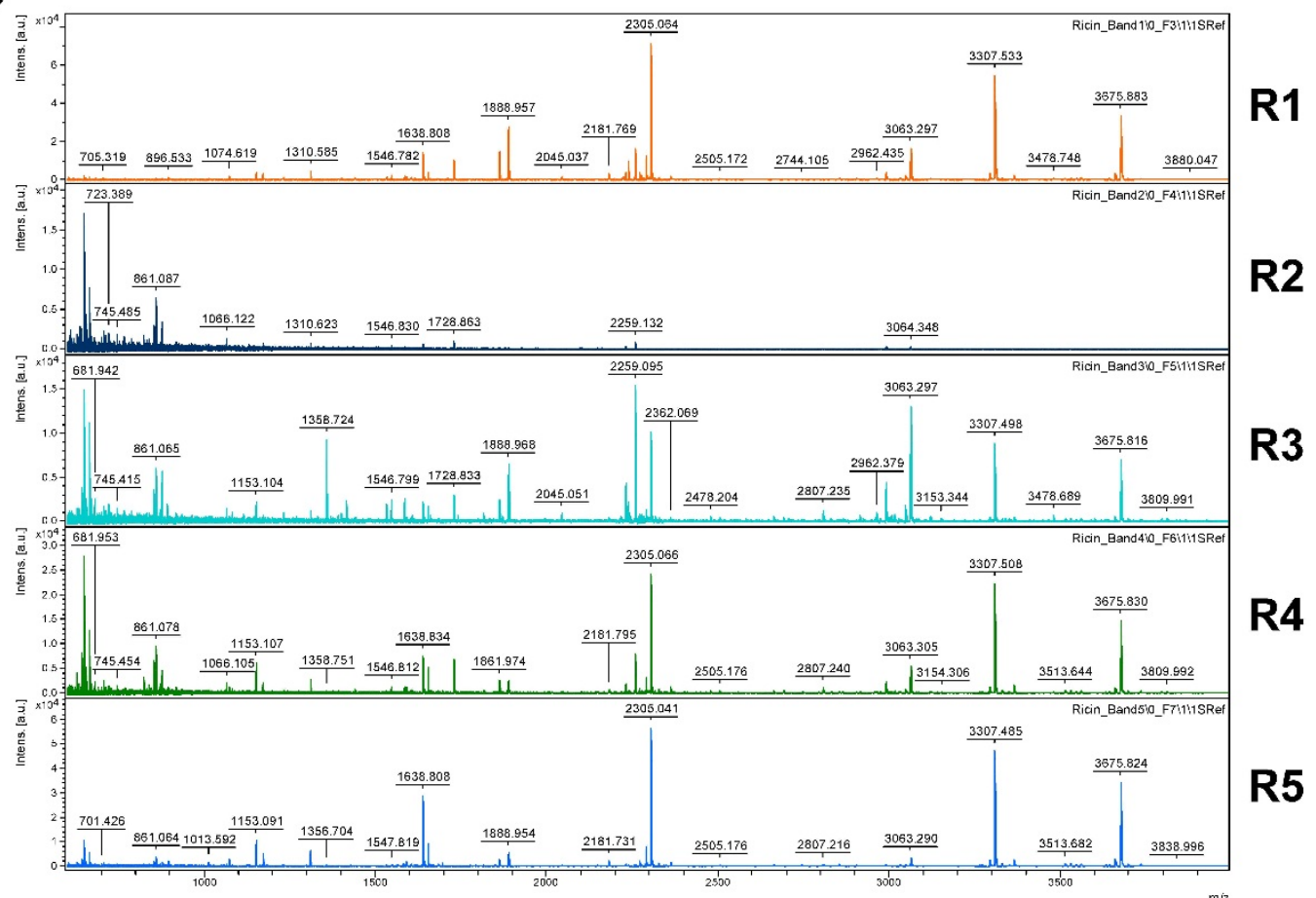

(b)

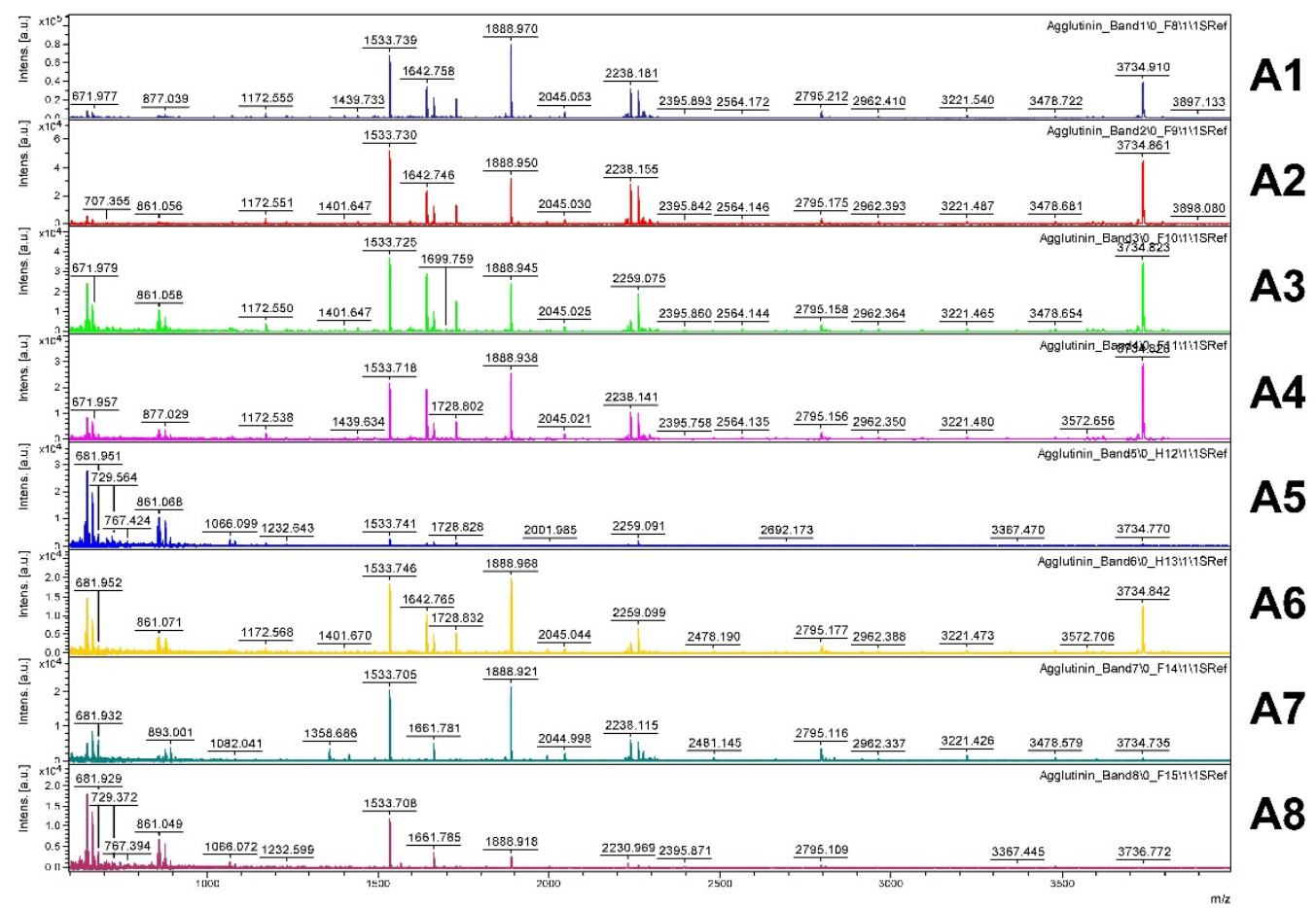

Figure 9. Overview spectra of trypsin-digested samples for gel lanes containing the purified ricin or RCA120 preparation. From top to bottom: analysis of (a) bands R1 through R5 of the ricin preparation and (b) bands A1 through A8 of the RCA120 preparation. Peaks are labeled with the corresponding $m / z$ value of the base peak.

Tables 7-9 list the specific peptides identified as products of trypsin digestion from chains A and B of ricin D (Uniprot [56] ID: P02879) as well from chain B of ricin E (Uniprot [56] ID: Q41143) which could be found in the mass spectra of the indicated gel bands. 
Table 7. Ricin D chain A-specific peptides obtained by trypsin digestion (Uniprot [56] ID: P02879, NCBI Genpept [57] ID: GI:132567) with one missed cleavage, reduced and carbamidomethylated in the mass range of 600-4000, and obtained by mass spectrometry analysis of the respective gel bands.

\begin{tabular}{cllccccc}
\hline Position & Amino Acid Sequence & $\mathbf{( M + H}^{+}$ & $\mathbf{R 1}^{*}$ & $\mathbf{R 2}^{*}$ & $\mathbf{R 3}^{*}$ & $\mathbf{R 4}^{*}$ & $\mathbf{R 5}^{*}$ \\
\hline $67-74$ & VGLPINQR & 896.5312 & $\mathrm{x}$ & - & - & $\mathrm{x}$ & $\mathrm{x}$ \\
$161-169$ & LEQLAGNLR & 1013.5738 & $\mathrm{x}$ & $\mathrm{x}$ & - & $\mathrm{x}$ & $\mathrm{x}$ \\
$150-160$ & YTFAFGGNYDR & 1310.5800 & $\mathrm{x}$ & $\mathrm{x}$ & $\mathrm{x}$ & $\mathrm{x}$ & $\mathrm{x}$ \\
$190-203$ & SFIICIQMISEAAR & 1638.8342 & $\mathrm{x}$ & $\mathrm{x}$ & $\mathrm{x}$ & $\mathrm{x}$ & $\mathrm{x}$ \\
$67-83$ & LTTGADVRHEIPVLPNR & 1888.0399 & $\mathrm{x}$ & - & $\mathrm{x}$ & $\mathrm{x}$ & $\mathrm{x}$ \\
$150-169$ & YTFAFGGNYDRLEQLAGNLR & 2305.1360 & $\mathrm{x}$ & - & $\mathrm{x}$ & $\mathrm{x}$ & $\mathrm{x}$ \\
$121-149$ & AGNSAYFFHPDNQEDAEAIT & 3307.5038 & $\mathrm{x}$ & - & $\mathrm{x}$ & $\mathrm{x}$ & $\mathrm{x}$ \\
& HLFTDVQNR & & & & & &
\end{tabular}

* R1-R5: Ricin band number of the one-dimensional gel electrophoresis; please compare Figure 8. Indicated by " $x$ " is the presence of the respective trypsin digest peptide shown.

Table 8. Ricin D chain B-specific peptides obtained by trypsin digestion (Uniprot [56] ID: P02879, NCBI GenPept [57] ID: GI:132567) with one missed cleavage, reduced and carbamidomethylated in the mass range of 600-4000, and obtained by mass spectrometry analysis of the respective gel bands.

\begin{tabular}{llcccccc}
\hline Position & Amino Acid Sequence & $\mathbf{( M + H}^{+}$ & R1 $^{*}$ & R2 $^{*}$ & R3 $^{*}$ & R4 $^{*}$ & R5 $^{*}$ \\
\hline $355-366$ & SNTDANQLWTLK & 1390.6961 & $\mathrm{x}$ & - & $\mathrm{x}$ & - & - \\
355-367 & SNTDANQLWTLKR & 1546.7972 & $\mathrm{x}$ & $\mathrm{x}$ & $\mathrm{x}$ & $\mathrm{x}$ & $\mathrm{x}$ \\
330-342 & FHNGNAIQLWPCK & 1584.7740 & $\mathrm{x}$ & - & $\mathrm{x}$ & $\mathrm{x}$ & - \\
534-550 & NDGTILNLYSGLVLDVR & 1862.0018 & $\mathrm{x}$ & - & $\mathrm{x}$ & $\mathrm{x}$ & $\mathrm{x}$ \\
$365-391$ & CLTTYGYSPGVYVMIYDCNTAATDATR & 3063.3532 & $\mathrm{x}$ & $\mathrm{x}$ & $\mathrm{x}$ & $\mathrm{x}$ & $\mathrm{x}$
\end{tabular}

${ }^{*}$ R1-R5: Ricin band number of the one-dimensional gel electrophoresis; please compare Figure 8. Indicated by " $x$ " is the presence of the respective trypsin digest peptide shown.

Table 9. Ricin E chain B-specific peptides obtained by trypsin digestion (Uniprot [56] ID: Q41143) with one missed cleavage, reduced and carbamidomethylated in the mass range of 600-4000, and obtained by mass spectrometry analysis of the respective gel bands.

\begin{tabular}{lllccccc}
\hline Position & Amino Acid Sequence & $\mathbf{( M + H}^{+}$ & $\mathbf{R 1}^{*}$ & $\mathbf{R 2}^{*}$ & $\mathbf{R 3}^{*}$ & $\mathbf{R 4}^{*}$ & $\mathbf{R}^{*}$ \\
\hline 220-236 & NDGTILNLYNGLVLDVR & 1889.0127 & $\mathrm{x}$ & - & $\mathrm{x}$ & $\mathrm{x}$ & $\mathrm{x}$
\end{tabular}

* R1-R5: Ricin band number of the one-dimensional gel electrophoresis; please compare Figure 8. Indicated by " $\mathrm{x}$ " is the presence of the respective trypsin digest peptide shown.

All ricin bands R1 to R5 contained ricin chains A and B. Ricin E chain B could be observed in the ricin bands 1 , and 3 to 5 . Cross-contamination of RCA120 in the ricin preparation was found in bands R1 and R3, but only in one RCA120 peptide fragment $(m / z$ 1533, SNTDWNQLWTLR). Based on these data, cross-contamination of RCA120 in the ricin preparation was very low, corroborating results obtained by the LC-ESI MS/MS analysis.

The corresponding specific trypsin digest peptides from RCA120, Uniprot [56] ID: P06750, are displayed in Tables 10 and 11. In the RCA120 preparation, only RCA120 peptides (Uniprot [56] ID: P06750) and no ricin peptides were detected by MALDI-TOF MS analysis. Measured peptides belonged to RCA120 chains A and B, while band 8 showed peptides for RCA120 chain B only.

In summary, one-dimensional gel electrophoresis showed that the ricin preparation can be separated into five distinct bands with one main fragment at about $63 \mathrm{kDa}$, whereas purified RCA120 can be separated into eight bands with two main fragments running at around $170 \mathrm{kDa}$. The identity of the ricin and RCA120 bands was verified by MALDI-TOF-MS/MS analysis after trypsin digestion. All ricin bands contained ricin chains A and B of ricin D (Uniprot [56] ID: P02879). Ricin bands 1 and 3 to 5 also contained ricin E (Uniprot [56] ID: Q41143), while bands R1 and R3 also contained one peptide fragment $(m / z 1533$, SNTDWNQLWTLR) of RCA120. The cross-contamination was negligible. In purified RCA120 only RCA120 (Uniprot [56] ID: P06750) and no ricin was detected. 
Measured peptides belonged to RCA120 chains A and B, while band 8 only showed peptides for RCA120 chain B. Most importantly, the MALDI-TOF-MS/MS experiments gave no indication of the presence of irrelevant proteins co-purified from the R. communis seeds.

Table 10. RCA120 chain A-specific peptides obtained by trypsin digestion (Uniprot [56] ID: P06750, NCBI Genpept [57] ID: GI113504) with one missed cleavage, reduced and carbamidomethylated in the mass range of 600-4000, and obtained by mass spectrometry analysis of the respective gel bands.

\begin{tabular}{|c|c|c|c|c|c|c|c|c|c|c|}
\hline Position & Amino Acid Sequence & $(\mathrm{M}+\mathrm{H})^{+}$ & A1 * & $\mathrm{A} 2$ * & A3 * & A4 * & A5 * & A6* & A7 * & A8* \\
\hline $73-80$ & VGLPISQR & 869.5203 & $x$ & $x$ & - & - & - & - & - & - \\
\hline $150-157$ & LEQLGGLR & 885.5152 & $x$ & $x$ & $x$ & $x$ & - & $x$ & - & - \\
\hline $190-203$ & SFMVCIQMISEAAR & 1642.7750 & $x$ & $x$ & $x$ & $x$ & $x$ & $x$ & - & - \\
\hline $64-80$ & HEIPVLPNRVGLPISQR & 1925.1079 & $\mathrm{x}$ & $x$ & - & - & - & - & - & - \\
\hline $263-281$ & FNVYDVSILIPIIALMVYR & 2238.2545 & $x$ & $x$ & $x$ & $\mathrm{x}$ & - & $x$ & $x$ & - \\
\hline $158-189$ & ENIELGTGPLEDAISALYYYSTCGTQIPTLAR & 3516.7202 & $x$ & $x$ & $x$ & $x$ & - & $x$ & - & - \\
\hline
\end{tabular}

* A1-A8: RCA120 band number of the one-dimensional gel electrophoresis; please compare Figure 8. Indicated by " $\mathrm{x}$ " is the presence of the respective trypsin digest peptide shown.

Table 11. RCA120 chain B-specific peptides obtained by trypsin digestion (Uniprot [56] ID: P06750, NCBI Genpept [57] ID: GI225114) with one missed cleavage, reduced and carbamidomethylated in the mass range of 600-4000, and obtained by mass spectrometry analysis of the respective gel bands.

\begin{tabular}{|c|c|c|c|c|c|c|c|c|c|c|}
\hline Position & Amino Acid Sequence & $(\mathrm{M}+\mathrm{H})^{+}$ & A1 * & $\mathrm{A} 2$ * & A3 * & $\mathrm{A} 4$ * & A5 * & A6 * & A7 * & A8* \\
\hline $343-354$ & SNTDWNQLWTLR & 1533.7444 & $x$ & $x$ & $x$ & $x$ & $x$ & $x$ & $x$ & $x$ \\
\hline $343-355$ & SNTDWNQLWTLRK & 1661.8394 & $x$ & $x$ & $x$ & $x$ & $x$ & $x$ & $x$ & $x$ \\
\hline
\end{tabular}

* A1-A8: RCA120 band number of the one-dimensional gel electrophoresis; please compare Figure 8 . Indicated by " " is the presence of the respective trypsin digest peptide shown.

\subsection{Detection of Ricin and RCA120 Using Antibody-Based Techniques}

In a next step, both the ricin and the RCA120 preparation purified in this work were detected using immunological methods. Two different sandwich enzyme-linked immunosorbent assays (ELISA) were used, one preferentially detecting ricin with only little cross-reactivity with RCA120 and the other one preferentially detecting RCA120 with low cross-reactivity with ricin. The ricin-specific ELISA was based on a combination of two monoclonal antibodies and detected both chains of ricin (R109 and R18 [70], Table 12), while the RCA120-specific ELISA combined a monoclonal with a polyclonal chicken antibody (mAb ARK4 [71] and chicken IgY RC22 [72], Table 12).

Table 12. Monoclonal and polyclonal antibodies used for immunological detection.

\begin{tabular}{cccccccc}
\hline \multirow{2}{*}{ Name } & \multirow{2}{*}{ Isotype } & \multicolumn{3}{c}{ Specificity Indirect ELISA } & \multicolumn{2}{c}{ Sandwich ELISA } \\
\cline { 3 - 7 } & & Ricin & RCA120 & A Chain & B Chain & Ricin & RCA120 \\
\hline R18 & mAb, IgG1k & +++ & + & +++ & - & +++ & + \\
R109 & mAb, IgG1k & +++ & ++++ & - & +++ & ++++ & + \\
ARK4 $§$ & mAb, IgG & + & ++++ & n.d. & n.d. & + & +++ \\
RC22 & pAb, IgY & ++++ & ++++ & ++++ & ++++ & +++ & +++ \\
\hline
\end{tabular}

$\overline{\S \mathrm{mAb} \text { ARK4 kindly provided by M. Avondet, Spiez Laboratory, Switzerland; reactivity of the indicated }}$ antibodies to ricin, RCA120, ricin A chain or ricin B chain is qualitatively indicated: - no reaction, + weak reaction, +++ strong reaction, ++++ very strong reaction; n.d., not determined.

In a validation study for the ricin-specific ELISA, the half maximal effective concentration $\left(\mathrm{EC}_{50}\right)$ of the ELISA as the point of highest precision with respect to quantification was determined at $115 \pm 32 \mathrm{pg} / \mathrm{mL}$ with a limit of detection of $2 \mathrm{pg} / \mathrm{mL}$. The working range of the ricin-specific ELISA as the range in which obtained results have a precision of $<20 \%$ and a trueness of $80 \%-120 \%$ was experimentally determined, and the lower and upper limits of quantification were determined at 
$5 \mathrm{pg} / \mathrm{mL}$ and $708 \mathrm{pg} / \mathrm{mL}$, respectively. Intra-assay and inter-assay coefficients of variation were determined at $6 \%$ and $13 \%$ at the $\mathrm{EC}_{50}$ value, respectively, with $n=10$ as the number of intra- or inter-assay repetitions performed in duplicate (data not shown).

Using this ELISA, purified ricin could be detected down to around $3 \mathrm{pg} / \mathrm{mL}$ (Figure 10a). In order to test for specificity, the related RCA120 was analyzed using the same sandwich ELISA. As shown in Figure 10a, when equivalent concentrations of ricin and RCA120 were tested in parallel, ricin was preferentially detected (300-fold difference at the $\mathrm{EC}_{50}$ ). However, at concentrations above $4 \mathrm{ng} / \mathrm{mL}$, RCA120 was detected as well. No cross-reactivity except for RCA120 to a broad range of other lectins and toxins was detected (data not shown). Still, based on the observed reactivity to both analytes, in a mixture containing ricin along with RCA120, assuming that both proteins were present in significant amounts, the ELISA would not be able to distinguish both molecules reliably. An alternative interpretation of the data would be that the ricin-specific ELISA is specific for ricin only and detects the minute contamination of ricin within the RCA120 preparation (below 1\% according to 2.2.1); this seems unlikely on the basis of the high sequence homology between both analytes, but cannot be ruled out since the precise epitopes recognized by both mAbs are not known. With respect to sensitivity, this ELISA is among the most sensitive sandwich ELISAs published to date. Various ELISAs have been developed by different groups [70,73-83]. Only a few of them are able to quantify ricin with detection limits down to a few $\mathrm{pg} / \mathrm{mL}$ with limits of detection of $10 \mathrm{fg} / \mathrm{mL}$ [84], $2 \mathrm{pg} / \mathrm{mL}$ [70], $8 \mathrm{pg} / \mathrm{mL}$ [85], and $40 \mathrm{pg} / \mathrm{mL}$ [86]. Several ricin-specific ELISAs developed in different laboratories have been evaluated in a common ricin proficiency test panel organized in the framework of the EQuATox project, and results are presented in different manuscripts in this special issue of Toxins $[42,87]$.

(a)

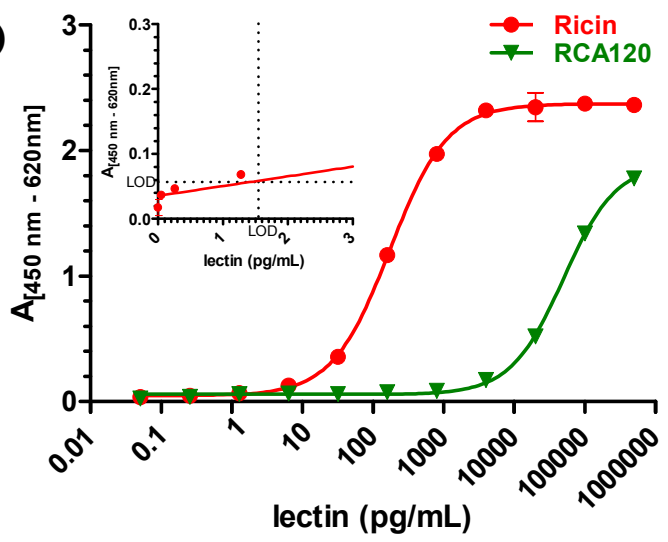

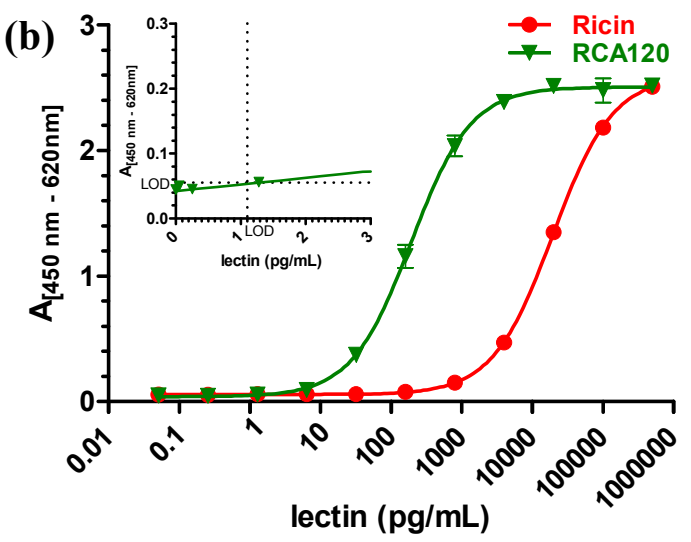

Figure 10. Sandwich ELISA for detection of purified ricin and purified RCA120. (a) A sandwich ELISA preferentially detecting ricin based on mAb R109 as capture antibody and biotinylated mAb R18 as detection antibody was used to measure serial dilutions of the purified ricin (red) or purified RCA120 (green) preparation; (b) A sandwich ELISA preferentially detecting RCA120 based on mAb ARK4 as capture reagent and biotinylated pAb RC22 as detection reagent was used to measure serial dilutions of ricin (red) or RCA120 (green). Both ELISAs were amplified using a polyHRP-conjugate and TMB substrate. Absorption was measured at $450 \mathrm{~nm}$ with a reference wavelength of $620 \mathrm{~nm}$. The absorption was plotted against the logarithmic concentrations of ricin or RCA120, respectively. Results displayed are based on two independent experiments performed in duplicate each. Inset: enlargement showing the low concentration range (linear) and estimated limit of detection $(\mathrm{LOD}=$ mean of blank $+3.29 \times \mathrm{SD})$.

Using the combination of mAb ARK4 with pAb RC22, purified RCA120 could be detected with a limit of detection around $1 \mathrm{pg} / \mathrm{mL}$ (Figure 10b). The $\mathrm{EC}_{50}$ was determined at $117 \mathrm{pg} / \mathrm{mL}$ $\pm 27 \mathrm{pg} / \mathrm{mL}$. The working range of the agglutinin-specific ELISA (precision of $<20 \%$; trueness of $80 \%-120 \%$ ) was experimentally determined and the lower and upper limits of quantification were 
determined at $3 \mathrm{pg} / \mathrm{mL}$ and $1549 \mathrm{pg} / \mathrm{mL}$, respectively. Intra-assay and inter-assay coefficients of variation were determined at $4 \%$ and $6 \%$ at the $\mathrm{EC}_{50}$ value, respectively, with $n=10$ as number of intra- or inter-assay repetitions performed in duplicate (data not shown).

When equivalent concentrations of RCA120 and ricin were tested in parallel with this RCA120-specific ELISA, RCA120 was preferentially detected (100-fold difference at the $\mathrm{EC}_{50}$ ). Again, at concentrations above $1 \mathrm{ng} / \mathrm{mL}$, ricin was detected as well (Figure 10b). Similar to the above, in a mixture containing significant amounts of ricin along with RCA120, the ELISA would not be able to distinguish both molecules reliably.

With respect to the ricin PT organized in the framework of the EQuATox project, both ELISAs were used to quantify the sample materials offered after spiking the purified ricin or RCA120 preparations into different liquid matrices (see this issue of Toxins: [42]).

\subsection{Functional Activity of Ricin and RCA120}

Ricin is a lectin and functions as an enzyme within the body: after binding to distinct carbohydrate structures on the cell surface via its B chain, the molecule is internalized and the A chain removes a single adenine from the $28 \mathrm{~S}$ rRNA of the ribosome, preventing further binding of elongation factors. This leads to an arrest of protein synthesis and finally results in cell death. Different in vitro assays have been developed to detect the functional activity of ricin, among them assays that detect the glycan-binding capacity of the B chain [88] or assays that detect the isolated enzymatic activity such as adenine release assays or cell-free translation assays based on rabbit reticulocyte lysate $[43,89,90]$. Since the detection of the activity of the isolated subchains provides only limited information on the activity of the intact ricin molecule, assays for both subchains are required for the detection of active ricin. In this context, cytotoxicity assays have found broad application, ranging from end-point assays to real-time cytotoxicity formats [45].

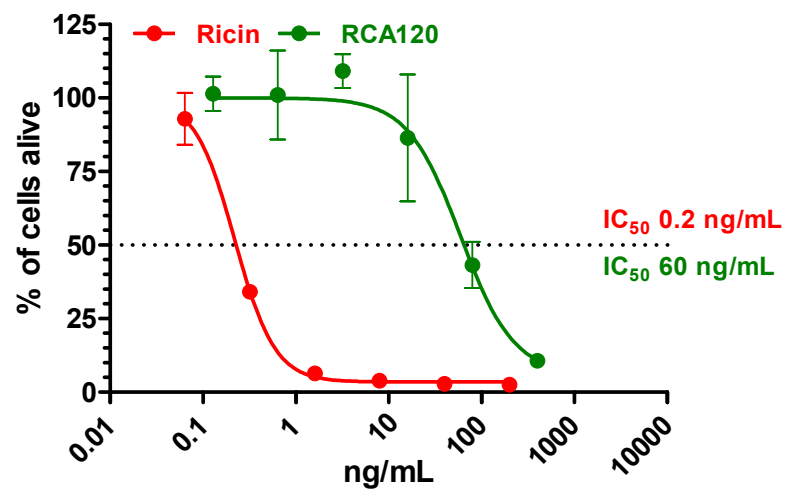

Figure 11. Real-time cytotoxicity assay to display the cytotoxic activity of the purified ricin and RCA120 preparations. Vero cells were seeded in a 96-well E-plate at 12,500 cells/well; immediately after seeding, cells were exposed to different concentrations of ricin (red) or RCA120 (green). Cell proliferation was dynamically monitored over $36 \mathrm{~h}$ using an xCelligence instrument (OMNI Life Science GmbH \& Co, Bremen, Germany [45]). For calculation of the $\mathrm{IC}_{50}$ values of ricin and RCA120, the percentage of cells alive was plotted against the concentration of ricin (red) or RCA120 (green) at $36 \mathrm{~h}$. Cell index of cells without treatment at $20 \mathrm{~h}$ was set to $100 \%$. Calculated $\mathrm{IC}_{50}$ for ricin was $0.2 \mathrm{ng} / \mathrm{mL}$ and for RCA120 $60 \mathrm{ng} / \mathrm{mL}$. One representative experiment out of two performed in triplicate is shown.

In this work, a real-time cytotoxicity assay based on impedance measurement was used to characterize both the purified ricin and the purified RCA120 preparation [45]. The cell proliferation and toxin-induced cell death of African green monkey (Vero) cells was monitored online using the xCELLigence system (OMNI Life Science GmbH \& Co. KG, Bremen, Germany). This system is based on an impedance sensor technology to quantify cell viability and proliferation noninvasively and 
without labeling. Cell proliferation, morphology, and adhesion are monitored in real time. Cells are seeded into E-plates with integrated microelectrodes. Upon low-voltage application an electric field is generated which is differentially modulated by the cells. The higher the number of cells attached to the plate surface, the higher the impedance monitored by the instrument is. This change in impedance is used as a read-out for cell viability [45].

Using a standardized protocol, Vero cells were incubated over $36 \mathrm{~h}$ with increasing concentrations of purified ricin or purified RCA120. In vitro cytotoxicity, where $50 \%$ of the cells were alive $\left(\mathrm{IC}_{50}\right)$, was calculated after $36 \mathrm{~h}$ by displaying the percentage of cells alive against the concentration of the lectin used in the test (Figure 11). For ricin, an $\mathrm{IC}_{50}$ of $0.2 \mathrm{ng} / \mathrm{mL}$ was calculated, while for RCA120, an $\mathrm{IC}_{50}$ of $60 \mathrm{ng} / \mathrm{mL}$ was determined. Based on these data, ricin is approximately 300-fold more toxic than RCA120 in the experimental system used. While it is well established that RCA120 is much less toxic than ricin, the difference in activity depends on the type of assay as well as on the purity and integrity of the lectin preparations used; differences in activity from 60-fold to 2000 -fold can be found in the literature [8,22-24].

\section{Experimental Section}

\subsection{Purification of Ricin and RCA120 and Determination of Protein Concentration}

Ricin and RCA120 were purified from the seeds of R. communis variety carmencita pink following protocols similar to those described earlier $[8,45,46]$. Briefly, the purification process consisted of an acid extraction at $\mathrm{pH} 4$ and an ammonium sulfate precipitation of proteins. Affinity separation using an in-house prepared lactosyl-Sepharose-4B column was used to isolate ricin and RCA120 from other constituents in the precipitate. Finally, size exclusion chromatography over HiLoad Superdex 200 prep grade (General Electrics, Health Care Life Sciences, Uppsala, Sweden) was used to separate ricin from RCA120.

For determination of the precise concentration of the purified ricin and purified agglutinin preparations, the absorption at $280 \mathrm{~nm}, 260 \mathrm{~nm}$, and $320 \mathrm{~nm}$ were measured in four independent dilutions using a NanoPhotometer (Implen, Munich, Germany) on two different days. Each dilution was measured five times. PBS was used as diluent and as blank reference. The average of the absorption values of each dilution was used to calculate the concentration of both toxin preparations according to Lambert-Beer's law:

$$
c=\frac{A 280}{\varepsilon} \times D F \times d
$$

with $c$ : concentration; A280: absorption at $280 \mathrm{~nm} ; \varepsilon$ : extinction coefficient; DF: dilution factor; $d$ : path length of cuvette and the following extinction coefficients: $\varepsilon$ (ricin) $=1.1615 \mathrm{~mL} \times \mathrm{mg}^{-1} \times \mathrm{cm}^{-1}$ (experimentally determined by Russmann et al. [52]), which was highly similar to $\varepsilon$ (ricin) $=1.17 \mathrm{~mL}$ $\times \mathrm{mg}^{-1} \times \mathrm{cm}^{-1}$ determined earlier and $\varepsilon$ (agglutinin) $=1.17 \mathrm{~mL} \times \mathrm{mg}^{-1} \times \mathrm{cm}^{-1}$ [6] .

\subsection{SDS-PAGE}

Ten percent SDS gels were run in a Mini-PROTEAN ${ }^{\circledR} 3$ System (Bio-Rad Laboratories, Munich, Germany). Proteins were separated either under non-reducing conditions or under reducing conditions using $\beta$-mercaptoethanol ( $\beta$-ME, SERVA Electrophoresis GmbH, Heidelberg, Germany) as reducing agent, followed by staining with Coomassie Brilliant Blue G250 (SERVA Electrophoresis $\mathrm{GmbH}$, Heidelberg, Germany).

\subsection{Capillary Gel Electrophoresis}

A Bio-Rad Experion electrophoresis instrument (Bio-Rad Laboratories, Hercules, CA, USA) was used with Pro260 chips and the manufacturer's reagent kit. Four $\mu \mathrm{L}$ of sample were mixed with the sample buffer and analyzed according to the manufacturer's protocol. 


\subsection{LC-ESI MS for Determination of Molecular Weight}

The LC-ESI MS measurements were carried out using the Thermo Finnigan LXQ linear ion trap mass spectrometer (Thermo Scientific, Waltham, MA, USA). The LC separation was done with the Thermo Finnigan Surveyor liquid chromatograph (Thermo Scientific, Waltham, MA, USA) using Supelco Discovery BIO Wide Pore C5 column (Sigma-Aldrich, Bellefonte, PA, USA) $(100 \times 2.1 \mathrm{~mm}$, $3 \mu \mathrm{m}$ particles, $300 \AA$ A pore size).

The LC separation was done using a gradient program: $0-7 \min 5 \%-50 \%$ B, $7-16 \min 50 \%-95 \%$, 16-21 $\min 95 \%$ B, 21-22 min 95\%-5\% B, 22-32 min 5\% B, where eluent A is ultra high quality water (reverse osmosis and ion exchange) with $0.1 \%$ of formic acid, and $\mathrm{B}$ is acetonitrile with $0.1 \%$ of formic acid. The injection volume was $10 \mu \mathrm{L}$.

The mass range for the measurements was $400-2000 \mathrm{~m} / z$ and the spectra were measured in the profile mode. The voltage of the ESI needle was $4 \mathrm{kV}$. The ion source capillary was kept at $290^{\circ} \mathrm{C}$ and at $42 \mathrm{~V}$. Sheat gas was kept at 20 (arbitrary units) and Aux gas at 4 (arb). Deconvolution was done using ProMass for Xcalibur (version 2.8, rev. 2, Novatia LLC, Newtown, PA, USA).

\subsection{LC-ESI MS for Tryptic Fingerprint and Sequencing}

For LC-MS analysis aliquots of purified ricin and purified RCA120 were digested with trypsin after reduction and alkylation according to published procedures [44]. Sample preparation and digestion was performed directly in a centrifugal cartridge with a $10 \mathrm{kDa}$ molecular weight cut-off membrane (Microcon YM-10, Merck Millipore, Billerica, MA, USA). Briefly, $50 \mu \mathrm{L}$ of the sample were transferred to the cartridge and centrifuged at $14,000 \times g$ until approximately $10 \mu \mathrm{L}$ remained. The reducing solution, $200 \mu \mathrm{L}$ of $3 \mathrm{mg} \mathrm{DTT} / \mathrm{mL}$ in guanidine buffer ( $6 \mathrm{M}$ guanidine $\mathrm{HCl}$ in $0.1 \mathrm{M}$ Tris $\mathrm{pH} 8$ ) was added and the sample was reduced at $60{ }^{\circ} \mathrm{C}$ for $1 \mathrm{~h}$. Then, $67 \mu \mathrm{L}$ of $7.5 \mathrm{mg}$ iodoacetamide $/ \mathrm{mL}$ in the guanidine buffer was added and the sample was alkylated at $37^{\circ} \mathrm{C}$ in the dark for $30 \mathrm{~min}$. The reduced and alkylated sample was centrifuged to approximately $10 \mu \mathrm{L}$ and washed twice with $200 \mu \mathrm{L}$ of $0.1 \mathrm{M}$ ammonium bicarbonate. The digestion buffer, $200 \mu \mathrm{L}$ of $0.1 \mathrm{M}$ ammonium bicarbonate, and $0.5 \mu \mathrm{g}$ of modified trypsin (Promega, sequencing grade) was added and the sample was digested for $6 \mathrm{~h}$ at $37^{\circ} \mathrm{C}$ before centrifugation to collect the digest peptides. The digests were stored at $-20^{\circ} \mathrm{C}$ until analysis.

A Waters nano-Acquity-Q-Tof Ultima LC-MS system equipped with a nanoflow electrospray ionization source was used for sample analysis (Micromass, Altrincham, UK). Digests were diluted $1: 50$ in $0.4 \%$ formic acid containing $5 \mathrm{fmol} / \mu \mathrm{L}$ of leucine-enkephalin internal standard. A $2-\mu \mathrm{L}$ sample was injected and trapped on a C18 trap column which was subsequently eluted onto a Waters BEH130 C18 $75 \mu \mathrm{m}$ in diameter, $150 \mathrm{~mm}$ column with a $3 \%-60 \%$ acetonitrile gradient containing $0.1 \%$ formic acid at $400 \mathrm{~nL} / \mathrm{min}$. The mass scale was calibrated using sodium formate clusters. Mass spectra were acquired over the mass range 300-1800 at 1 scan/s. Precursor ions were selected with a 3 Da mass window, and product ion spectra were recorded from 100 and up to a mass appropriate for each of the precursor ions.

\subsection{MALDI TOF-MS}

First, $15.1 \mu \mathrm{g}$ of ricin and $10.3 \mu \mathrm{g}$ of RCA120 were separated on a non-reducing $10 \%$ SDS-PAGE. Coomassie-stained gel bands were cut out with a clean scalpel, divided into equal sections of approximately $1.5 \mathrm{~mm}$ size, and transferred into Eppendorf (Hamburg, Germany) LoBind tubes. In order to destain the protein bands, gel pieces were covered twice with $200 \mu \mathrm{L}$ of $200 \mathrm{mM}$ ammonium bicarbonate $/ 40 \%$ acetonitrile for $30 \mathrm{~min}$ at $37^{\circ} \mathrm{C}$. Reduction was performed with $15 \mu \mathrm{L}$ of $400 \mathrm{mM}$ dithiothreitol for $10 \mathrm{~min}$ at $95^{\circ} \mathrm{C}$. Alkylation was carried out using $30 \mu \mathrm{L}$ of $500 \mathrm{mM}$ iodoacetamide at $37^{\circ} \mathrm{C}$ for $30 \mathrm{~min}$ in the dark. Reduced and alkylated samples were digested with $20 \mu \mathrm{L}$ of trypsin $(0.4 \mu \mathrm{g})$ (Sigma-Aldrich, Taufkirchen, Germany, proteomics grade) at $37^{\circ} \mathrm{C}$ overnight. Reaction was terminated with $50 \mu \mathrm{L}$ of $0.1 \%$ trifluoroacetic acid $/ 50 \%$ acetonitrile, for $30 \mathrm{~min}$ at $37^{\circ} \mathrm{C}$. Digested 
peptides were further desalted and concentrated with ZipTip C18 resin (Merck Millipore, Darmstadt, Germany) carried out according to manufacturer's instructions.

Sample analysis was done utilizing an autoflex speed MALDI-TOF/TOF mass spectrometer (Bruker Daltonics, Bremen, Germany) with a polished steel MTP 384 target plate (Bruker Daltonics, Bremen, Germany). One $\mu \mathrm{L}$ sample was mixed with $1 \mu \mathrm{L}$ of $\alpha$-Cyano-4-hydroxycinnamic acid (12 mg/mL; Bruker Daltonics, Bremen, Germany), and $1 \mu \mathrm{L}$ was deposited on the target to let it dry. For matrix suppression deflection was set to 600, and mass spectra were acquired over the mass range 600-4000. External calibration was performed with peptide calibration standard II (Bruker Daltonics, Bremen, Germany). Spectra were processed by flexAnalysis 2.4 and BioTools 3.2 software (Bruker Daltonics, Bremen, Germany).

\subsection{ELISA}

The ricin-specific ELISA was performed essentially as described before [70], using mAb antibody R109 as capture antibody and biotinylated R18 as detection tool, followed by a streptavidin-poly-horseradish peroxidase conjugate (PolyHRP40). Briefly, MaxiSorp microtiter plates were coated with primary $\mathrm{mAb}(10 \mu \mathrm{g} / \mathrm{mL})$ in $50 \mu \mathrm{L}$ of PBS overnight at $4{ }^{\circ} \mathrm{C}$ and blocked with casein buffer (Senova, Jena, Germany) for $1 \mathrm{~h}$ at room temperature. Following washing, $50 \mu \mathrm{L}$ of toxin was added in serial dilutions from $100 \mathrm{ng} / \mathrm{mL}$ to $0.05 \mathrm{pg} / \mathrm{mL}$ in assay buffer (PBS, 0.1\% BSA (Sigma-Aldrich, Munich, Germany)) and incubated for $2 \mathrm{~h}$ at room temperature. The sandwich ELISA was developed by incubation with biotin-labeled secondary antibody diluted in casein buffer ( $1 \mathrm{~h}$, room temperature), followed by washing and detection with Streptavidin-PolyHRP40 $(0.5 \mathrm{ng} / \mathrm{mL}$, Senova, Jena, Germany) and substrate

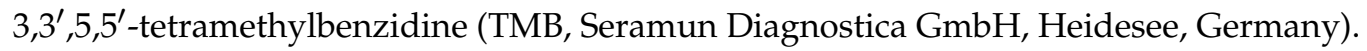

The RCA120-specific ELISA was performed similarly, using mAb ARK4 (kindly provided by Marc-André Avondet, Spiez Laboratory, Switzerland; [71]) as capture antibody and biotinylated polyclonal chicken IgY RC22 [72] as detection antibody.

\subsection{Cytotoxicity Assay}

Measurement of the cytotoxicity of ricin and RCA120 was performed by a real-time cytotoxicity assay based on impedance measurement (xCELLigence system, OMNI Life Science GmbH \& Co, Bremen, Germany) as described before [45]. Briefly, after baseline measurement of the E-plate, a Vero cell suspension containing 12,500 cells/well in a volume of $75 \mu \mathrm{L}$ was seeded into the E-plates. Immediately after the seeding of cells into the wells (i.e., without prior attachment of the cells onto the plate), purified ricin or purified RCA120 at concentrations of $0.064 \mathrm{ng} / \mathrm{mL}$ to $200 \mathrm{ng} / \mathrm{mL}$ for ricin or $0.128 \mathrm{ng} / \mathrm{mL}$ to $400 \mathrm{ng} / \mathrm{mL}$ for RCA120 were added onto the cells in a volume of $30 \mu \mathrm{L}$. Each sample was measured at least in duplicate. The cell index was automatically determined every $15 \mathrm{~min}$ by the xCELLigence system over a period of up to $36 \mathrm{~h}$. During the incubation, only live cells attached onto the plate and showed vigorous proliferation (equivalent to an increase in impedance and cell index). Depending on the toxin concentration present on the cells, the proliferation was terminated after different time points, followed by detachment and cell death (equivalent to a drop of impedance and cell index). Cell viability was converted into percent (\%) of the control cells alive over toxin concentration. To this end, the cell index of nontreated cells measured at several time-points was set to $100 \%$, and for a given time-point the ratio of cell index values of toxin-treated cells to untreated cells was calculated. In vitro cytotoxicity at $50 \%\left(\mathrm{IC}_{50}\right)$ was defined as the toxin concentrations required to reduce cell viability by $50 \%$ compared to untreated control cells [45].

\section{Conclusions}

Although different technologies for the detection and identification of the plant toxin ricin as a potential biological weapon under the BWC and CWC have been established worldwide, hardly any universally agreed-upon "gold standards" are available, i.e., common internationally recognized 
reference materials. The current situation is that expert laboratories use differently purified in-house materials of variable quality for their own validation purposes, making any comparison of accuracy and sensitivity of different methods nearly impossible. The current work has been undertaken in an effort to generate highly pure and well-characterized materials that can be used as a starting point to develop certified reference materials.

In this work, the plant toxin ricin and the highly homologous $R$. communis agglutinin RCA120 were purified from the seeds of $R$. communis variety carmencita pink to a purity of $>97 \%$ and $>99 \%$, respectively. Both protein preparations were extensively characterized using biochemical, spectrometric, immunological, and functional approaches combining technical expertise available in different European laboratories in the framework of the EU-funded project EQuATox. Based on the in-depth characterization performed in different European expert laboratories, the protein preparations represent reference materials of high quality which were later used in an international proficiency test [42]. Indeed, in this exercise a consensus concentration was determined for the ricin reference material based on different technological approaches available in independent expert laboratories, indicating that the comparability of results was achieved [42].

The employed mass spectrometric analyses on tryptically digested materials revealed peptides suitable for the identification and quantification of ricin isoforms and RCA120, i.e., peptides that are proteotypic and detected at high intensity, and our results are in good agreement with previously published data obtained with independent or commercial ricin preparations of different quality. Recommendations are given as to which and how many peptides should be used to identify ricin $D$, ricin E, and RCA120 unambiguously, and this information is potentially important in the course of a forensic investigation.

As screening methods, two different ELISA methods were presented that preferentially detect either ricin or RCA120 with only very little cross-reactivity between the two homologous analytes down to the low $\mathrm{pg} / \mathrm{mL}$ range, a concentration range that is relevant in the context of human ricin intoxications (own unpublished data and [91]). While the ELISA-based methods are not suitable for the unambiguous identification of ricin, they are most sensitive to detect ricin-containing samples in the low $\mathrm{pg} / \mathrm{mL}$ range which is usually not covered by spectrometric approaches. Also, the applied $\mathrm{mAb}$ can effectively be used for immunoaffinity enrichment of ricin from complex matrices followed by MS-based identification, combining and improving both technical approaches $[62,92,93]$. Generally, it has to be considered that antibody binding might be affected by the glycosylation of ricin/RCA120, and interference could occur if the epitope recognized by an antibody contains or is adjacent to a specific glycosylation site. However, when the ricin-ELISA described in this work was used to detect ricin prepared from seven different cultivars of $R$. communis, no differences were observed when equivalent amounts of toxin were tested (not shown).

In terms of function, a real-time cytotoxicity assay showed that the ricin reference material prepared was approximately 300-fold more toxic than the corresponding RCA120 preparation, with an $\mathrm{IC}_{50}$ value of $0.2 \mathrm{ng} / \mathrm{mL}$ for ricin and $60 \mathrm{ng} / \mathrm{mL}$ for RCA120. Exemplarily, previously published $\mathrm{IC}_{50}$ values for ricin were determined at $8-60 \mathrm{ng} / \mathrm{mL}[29]$ and $0.14-0.4 \mathrm{ng} / \mathrm{mL}[45,94]$ and showed that the precise $\mathrm{IC}_{50}$ value depends on different analytical parameters such as the cell line used for the cytotoxicity assay, kinetics, purity, integrity, and post-translational modification of the toxin used. Evaluation of toxicity in mice provided evidence for ricin being about 40-80-fold more toxic than RCA120 [24], but comparative data on non-human primates are not available [95]. Overall, comparison of the toxicity data is difficult as often no detailed information on the purity, lectin composition, or the cultivar used is available. On the other hand, rodent and non-human primate models have been valuable to delineate the pathophysiology of ricin toxicosis after systemic, oral, or aerosol exposure or to analyze the efficacy of potential therapeutic agents [96].

In the context of protein function it would be interesting to extend the characterization further to i) the identification of glycosylation patterns of the ricin isoforms isolated; ii) the precise quantification of constituent ricin isoforms (D and E) in the mixture; and iii) the elucidation of 
secondary structures to highlight and follow the integrity of the molecules over time (e.g., by using circular dichroism spectroscopy). Finally, it might be interesting to compare results obtained with ricin reference material isolated from different cultivars of $R$. communis for additional validation of identification and quantification methods. Especially glycosylation has been shown to be important for protein function, and different glycosylation correlates with different toxicities [29]: of three differently glycosylated ricin isoforms tested, the highest glycosylated form, containing more hybrid/complex-type glycans with mannose as hexose units, has been shown to be most toxic in different assay systems. Along the same line, the chemically deglycosylated ricin A chain is about 1000-fold less toxic than the glycosylated ricin A chain in mice [97]. Furthermore, $\mathrm{N}$-glycosylation has been shown to promote the toxicity of the ricin A chain by promoting its transport out of the endoplasmic reticulum [98]. Overall, there is convincing evidence showing that glycosylation and especially the type of glycosylation of ricin does affect the function of the molecule, a fact that is well known for a range of different proteins [99]. This is currently seen as a counter-argument against the production of ricin reference material as a recombinant protein in prokaryotic or eukaryotic expression systems (e.g., E. coli, P. pastoris or tobacco plants), which was a successful approach for vaccine development [100]. To have the authentic glycosylation pattern or post-translational modification, in general, on a ricin reference material purified from natural sources seems to outweigh advantages of recombinant technologies such as the higher uniformity of proteins produced. However, recombinant technologies or, in light of the cellular toxicity of ricin, cell-free expression systems could be the way forward to produce stable isotope-labeled ricin that could be used in the analytical workflow to determine sample preparation recovery rates or to document the reproducibility of analytical procedures (e.g., enzymatic digestion efficiency for spectrometric approaches). A prerequisite for using this approach, however, is that the pure (nonglycosylated) isotopically labeled protein behaves the same way as the authentic protein.

Taken together, the experience acquired in this study can be exploited further in a next step to develop certified ricin and RCA120 reference materials that would be available to international expert laboratories. To place the activities in a larger context, decision-makers rely on correct and reliable laboratory data in order to make appropriate decisions. Reliable detection, identification, and quantification of ricin and RCA120 as well as their discrimination requires highly pure and well-characterized reference materials. Due to the fact that ricin is classified as a C-weapon, this issue could well be driven forward by internationally funded projects with technological expert support from different nations and standardization bodies. Based on this, the cornerstones of the next developments in the process of harmonization of analytical approaches would be highly specific tools, thoroughly validated analytical procedures, recommended standard operating procedures, well-trained personnel, and regular training in proficiency tests or ring trials.

Supplementary Materials: Supplementary materials can be accessed at: http://www.mdpi.com/2072-6651/7/ $12 / 4856 / \mathrm{s} 1$.

Acknowledgments: The research leading to any result within the EQuATox project has received funding from the European Community's Seventh Framework Programme (FP7/2007-2013) under grant agreement no. 285120 which is greatly acknowledged by the authors and participants. We are grateful to Jacek Millert (Robert Koch Institute, Berlin, Germany) for expert technical support and to Ursula Erikli for copy-editing.

Author Contributions: Designed, performed experiments and interpreted data: Sylvia Worbs, Martin Skiba, Martin Söderström, Marja-Leena Rapinoja, Heiko Russmann, Sten-Åke Fredriksson, and Brigitte G. Dorner. Contributed reagents and technical expertise: Reinhard Zeleny, Heinz Schimmel, and Paula Vanninen. Wrote the manuscript: Sylvia Worbs, Reinhard Zeleny, Sten-Åke Fredriksson, and Brigitte G. Dorner.

Conflicts of Interest: The authors declare no conflict of interest.

\section{References}

1. Stillmark, H. Über Ricin, ein Giftiges Fragment aus den Samen von Ricinus Comm. L. und Einigen anderen Euphorbiaceen; Kaiserliche Universität zu Dorpat (University of Tartu): Tartu, Estonia, 1888. (In German) 
2. Hartley, M.R.; Lord, J.M. Genetics of ribosome-inactivating proteins. Mini Rev. Med. Chem. 2004, 4, 487-492. [CrossRef] [PubMed]

3. Lappi, D.A.; Kapmeyer, W.; Beglau, J.M.; Kaplan, N.O. The disulfide bond connecting the chains of ricin. Proc. Natl. Acad. Sci. USA 1978, 75, 1096-1100. [CrossRef] [PubMed]

4. Worbs, S.; Köhler, K.; Pauly, D.; Avondet, M.A.; Schaer, M.; Dorner, M.B.; Dorner, B.G. Ricinus communis intoxications in human and veterinary medicine-A summary of real cases. Toxins 2011, 3, 1332-1372. [CrossRef] [PubMed]

5. Baenziger, J.U.; Fiete, D. Structural determinants of Ricinus communis agglutinin and toxin specificity for oligosaccharides. J. Biol. Chem. 1979, 254, 9795-9799. [PubMed]

6. Olsnes, S.; Saltvedt, E.; Pihl, A. Isolation and comparison of galactose-binding lectins from Abrus precatorius and Ricinus communis. J. Biol. Chem. 1974, 249, 803-810. [PubMed]

7. Sandvig, K.; van Deurs, B. Endocytosis and intracellular transport of ricin: Recent discoveries. FEBS Lett. 1999, 452, 67-70. [CrossRef]

8. Lin, T.T.S.; Li, S.S.L. Purification and physicochemical properties of ricins and agglutinins from Ricinus communis. Eur. J. Biochem. 1980, 105, 453-459. [PubMed]

9. Olsnes, S.; Pihl, A. Different biological properties of the two constituent peptide chains of ricin, a toxic protein inhibiting protein synthesis. Biochemistry 1973, 12, 3121-3126. [CrossRef] [PubMed]

10. Tomita, M.; Kurokawa, T.; Onozaki, K.; Ichiki, N.; Osawa, T.; Ukita, T. Purification of galactose-binding phytoagglutinins and phytotoxin by affinity column chromatography using sepharose. Cell Mol. Life Sci. 1972, 28, 84-85. [CrossRef]

11. Bellisola, G.; Fracasso, G.; Ippoliti, R.; Menestrina, G.; Rosén, A.; Soldà, S.; Udali, S.; Tomazzolli, R.; Tridente, G.; Colombatti, M. Reductive activation of ricin and ricin A-chain immunotoxins by protein disulfide isomerase and thioredoxin reductase. Biochem. Pharmacol. 2004, 67, 1721-1731. [CrossRef] [PubMed]

12. Spooner, R.A.; Watson, P.D.; Marsden, C.J.; Smith, D.C.; Moore, K.A.H.; Cook, J.P.; Lord, J.M.; Roberts, L.M. Protein disulphide-isomerase reduces ricin to its $\mathrm{A}$ and $\mathrm{B}$ chains in the endoplasmic reticulum. Biochem. J. 2004, 383, 285-293. [CrossRef] [PubMed]

13. Chiou, J.-C.; Li, X.-P.; Remacha, M.; Ballesta, J.P.G.; Tumer, N.E. The ribosomal stalk is required for ribosome binding, depurination of the rRNA and cytotoxicity of ricin A chain in Saccharomyces cerevisiae. Mol. Microbiol. 2008, 70, 1441-1452. [CrossRef] [PubMed]

14. Lord, M.J.; Jolliffe, N.A.; Marsden, C.J.; Pateman, C.S.C.; Smith, D.C.; Spooner, R.A.; Watson, P.D.; Roberts, L.M. Ricin: Mechanisms of cytotoxicity. Toxicol. Rev. 2003, 22, 53-64. [CrossRef] [PubMed]

15. Sokołowska, I.; Wälchli, S.; Węgrzyn, G.; Sandvig, K.; Słomińska-Wojewódzka, M. A single point mutation in ricin A-chain increases toxin degradation and inhibits EDEM1-dependent ER retrotranslocation. Biochem. J. 2011, 436, 371-385. [CrossRef] [PubMed]

16. Sweeney, E.C.; Tonevitsky, A.G.; Temiakov, D.E.; Agapov, I.I.; Saward, S.; Palmer, R.A. Preliminary crystallographic characterization of ricin agglutinin. Proteins Struct. Funct. Bioinf. 1997, 28, 586-589. [CrossRef]

17. Araki, T.; Funatsu, G. The complete amino acid sequence of the B-chain of ricin E isolated from small-grain castor bean seeds. Ricin $\mathrm{E}$ is a gene recombination product of ricin D and Ricinus communis agglutinin. Biochim. Biophys. Acta 1987, 911, 191-200. [CrossRef]

18. Ladin, B.F.; Murray, E.E.; Halling, A.C.; Halling, K.C.; Tilakaratne, N.; Long, G.L.; Houston, L.L.; Weaver, R.F. Characterization of a cDNA encoding ricin E, a hybrid ricin-Ricinus communis agglutinin gene from the castor plant Ricinus communis. Plant Mol. Biol. 1987, 9, 287-295. [CrossRef] [PubMed]

19. Mise, T.; Funatsu, G.; Ishiguro, M.; Funatsu, M. Isolation and characterization of ricin E from castor beans. Agric. Biol. Chem. 1977, 41, 2041-2046. [CrossRef]

20. Roberts, L.M.; Lamb, F.I.; Pappin, D.J.; Lord, J.M. The primary sequence of Ricinus communis agglutinin. Comparison with ricin. J. Biol. Chem. 1985, 260, 15682-15686. [PubMed]

21. Cawley, D.B.; Hedblom, M.L.; Houston, L.L. Homology between ricin and Ricinus communis agglutinin: Amino terminal sequence analysis and protein synthesis inhibition studies. Arch. Biochem. Biophys. 1978, 190, 744-755. [CrossRef]

22. Saltvedt, E. Structure and toxicity of pure ricinus agglutinin. Biochim. Biophys. Acta 1976, 451, 536-548. [CrossRef] 
23. Olsnes, S.; Refsnes, K.; Pihl, A. Mechanism of action of the toxic lectins abrin and ricin. Nature 1974, 249, 627-631. [CrossRef] [PubMed]

24. Zhan, J.; Zhou, P. A simplified method to evaluate the acute toxicity of ricin and ricinus agglutinin. Toxicology 2003, 186, 119-123. [CrossRef]

25. Chan, A.P.; Crabtree, J.; Zhao, Q.; Lorenzi, H.; Orvis, J.; Puiu, D.; Melake-Berhan, A.; Jones, K.M.; Redman, J.; Chen, G.; et al. Draft genome sequence of the oilseed species Ricinus communis. Nat. Biotechnol. 2010, 28, 951-956. [CrossRef] [PubMed]

26. Leshin, J.; Danielsen, M.; Credle, J.J.; Weeks, A.; O'Connell, K.P.; Dretchen, K. Characterization of ricin toxin family members from Ricinus communis. Toxicon 2010, 55, 658-661. [CrossRef] [PubMed]

27. Despeyroux, D.; Walker, N.; Pearce, M.; Fisher, M.; McDonnell, M.; Bailey, S.C.; Griffiths, G.D.; Watts, P. Characterization of ricin heterogeneity by electrospray mass spectrometry, capillary electrophoresis, and resonant mirror. Anal. Biochem. 2000, 279, 23-36. [CrossRef] [PubMed]

28. Sehgal, P.; Khan, M.; Kumar, O.; Vijayaraghavan, R. Purification, characterization and toxicity profile of ricin isoforms from castor beans. Food Chem. Toxicol. 2010, 48, 3171-3176. [CrossRef] [PubMed]

29. Sehgal, P.; Kumar, O.; Kameswararao, M.; Ravindran, J.; Khan, M.; Sharma, S.; Vijayaraghavan, R.; Prasad, G.B.K.S. Differential toxicity profile of ricin isoforms correlates with their glycosylation levels. Toxicology 2011, 282, 56-67. [CrossRef] [PubMed]

30. Bergström, T.; Fredriksson, S.-Å.; Nilsson, C.; Åstot, C. Deamidation in ricin studied by capillary zone electrophoresis- and liquid chromatography-mass spectrometry. J. Chromatogr. B Anal. Technol. Biomed. Life Sci. 2015, 974, 109-117. [CrossRef] [PubMed]

31. Ogunniyi, D.S. Castor oil: A vital industrial raw material. Bioresour. Technol. 2006, 97, 1086-1091. [CrossRef] [PubMed]

32. Schieltz, D.M.; McGrath, S.C.; McWilliams, L.G.; Rees, J.; Bowen, M.D.; Kools, J.J.; Dauphin, L.A.; Gomez-Saladin, E.; Newton, B.N.; Stang, H.L.; et al. Analysis of active ricin and castor bean proteins in a ricin preparation, castor bean extract, and surface swabs from a public health investigation. Forensic Sci. Int. 2011, 209, 70-79. [CrossRef] [PubMed]

33. Moran, G.J. Threats in bioterrorism. II: CDC category B and C agents. Emerg. Med. Clin. North. Am. 2002, 20, 311-330. [CrossRef]

34. Crompton, R.; Gall, D. Georgi Markov—Death in a pellet. Med. Leg. J. 1980, 48, 51-62. [PubMed]

35. Schep, L.J.; Temple, W.A.; Butt, G.A.; Beasley, M.D. Ricin as a weapon of mass terror-separating fact from fiction. Environ. Int. 2009, 35, 1267-1271. [CrossRef] [PubMed]

36. Audi, J.; Belson, M.; Patel, M.; Schier, J.; Osterloh, J. Ricin poisoning: A comprehensive review. J. Am. Med. Assoc. 2005, 294, 2342-2351. [CrossRef] [PubMed]

37. Hayden, E.C.; Wadman, M. US ricin attacks are more scary than harmful. Nat. News 2013. [CrossRef]

38. Franz, D.R.; Jaax, N.K. Ricin toxin. In Medical Aspects of Chemical and Biological Warfare; Sidell, F.R., Takafuji, E.T., Franz, D.R., Eds.; TMM Publications: Washington, DC, USA, 1997; pp. 631-642.

39. Kirby, R. Ricin toxin: A military history. CML Army Chem. Rev. 2004, PB 3-04-1, 38-40.

40. Zilinskas, R.A. Iraq's biological weapons. J. Am. Med. Assoc. 1997, 278, 418-424. [CrossRef]

41. EQuATox. Available online: http://www.equatox.eu/ (accessed on 30 October 2015).

42. Worbs, S.; Skiba, M.; Bender, J.; Zeleny, R.; Schimmel, H.; Luginbühl, W.; Dorner, B.G. An international proficiency test to detect, identify and quantify ricin in complex matrices. Toxins 2015, 7. [CrossRef]

43. Schieltz, D.M.; McWilliams, L.G.; Kuklenyik, Z.; Prezioso, S.M.; Carter, A.J.; Williamson, Y.M.; McGrath, S.C.; Morse, S.A.; Barr, J.R. Quantification of ricin, RCA and comparison of enzymatic activity in 18 Ricinus communis cultivars by isotope dilution mass spectrometry. Toxicon 2015, 95, 72-83. [CrossRef] [PubMed]

44. Fredriksson, S.-Å.; Hulst, A.G.; Artursson, E.; de Jong, A.L.; Nilsson, C.; van Baar, B.L. Forensic identification of neat ricin and of ricin from crude castor bean extracts by mass spectrometry. Anal. Chem. 2005, 77, 1545-1555. [CrossRef] [PubMed]

45. Pauly, D.; Worbs, S.; Kirchner, S.; Shatohina, O.; Dorner, M.B.; Dorner, B.G. Real-time cytotoxicity assay for rapid and sensitive detection of ricin from complex matrices. PLoS ONE 2012, 7. [CrossRef] [PubMed]

46. Hegde, R.; Podder, S.K. Studies on the variants of the protein toxins ricin and abrin. Eur. J. Biochem. 1992, 204, 155-164. [CrossRef] [PubMed] 
47. Bradford, M.M. A rapid and sensitive method for the quantitation of microgram quantities of protein utilizing the principle of protein-dye binding. Anal. Biochem. 1976, 72, 248-254. [CrossRef]

48. Lowry, O.H.; Rosebrough, N.J.; Farr, A.L.; Randall, R.J. Protein measurement with the Folin phenol reagent. J. Biol. Chem. 1951, 193, 265-275. [PubMed]

49. Muñoz, A.; Kral, R.; Schimmel, H. Quantification of protein calibrants by amino acid analysis using isotope dilution mass spectrometry. Anal. Biochem. 2011, 408, 124-131. [CrossRef] [PubMed]

50. Peterson, G.L. Determination of total protein. Methods Enzymol. 1983, 91, 95-119. [PubMed]

51. Kim, S.-K.; Hancock, D.K.; Wang, L.; Cole, K.D.; Reddy, P.T. Methods to characterize ricin for the development of reference materials. J. Res. Natl. Inst. Stand. Technol. 2006, 111, 313-324. [CrossRef]

52. Russmann, H.; Russmann, A.; Heinrich, J.U. Aufreinigung von Ricin zur Herstellung eines Standards für Immunologische Untersuchungen; Bundeswehr Research Institute for Protective Technologies: Munster, Germany, 2009.

53. Brinkworth, C.S.; Pigott, E.J.; Bourne, D.J. Detection of intact ricin in crude and purified extracts from castor beans using matrix-assisted laser desorption ionization mass spectrometry. Anal. Chem. 2009, 81, 1529-1535. [CrossRef] [PubMed]

54. Kimura, Y.; Hase, S.; Kobayashi, Y.; Kyogoku, Y.; Ikenaka, T.; Funatsu, G. Structures of sugar chains of ricin D. J. Biochem. 1988, 103, 944-949. [PubMed]

55. Na, D.H.; Cho, C.K.; Youn, Y.S.; Choi, Y.; Lee, K.R.; Yoo, S.D.; Lee, K.C. Capillary electrophoresis to characterize ricin and its subunits with matrix-assisted laser desorption/ionization time-of-flight mass spectrometry. Toxicon 2004, 43, 329-335. [CrossRef] [PubMed]

56. UniProt. Available online: http://www.uniprot.org (accessed on 11 November 2015).

57. NCBI-National Center for Biotechnology Information. Available online: http://www.ncbi.nlm.nih.gov (accessed on 11 November 2015).

58. Araki, T.; Funatsu, G. Revised amino acid sequence of the B-chain of ricin D due to loss of tryptophan in the cyanogen bromide cleavage. FEBS Lett. 1985, 191, 121-124. [CrossRef]

59. Funatsu, G.; Kimura, M.; Funatsu, M. Primary structure of Ala chain of ricin D. Agric. Biol. Chem. 1979, 43, 2221-2224. [CrossRef]

60. Halling, K.C.; Halling, A.C.; Murray, E.E.; Ladin, B.F.; Houston, L.L.; Weaver, R.F. Genomic cloning and characterization of a ricin gene from Ricinus communis. Nucleic Acids Res. 1985, 13, 8019-8033. [CrossRef] [PubMed]

61. Fredriksson, S.-Å.; Artursson, E.; Bergström, T.; Östin, A.; Nilsson, C.; Åstot, C. Identification of RIP-II toxins by affinity enrichment, enzymatic digestion and LC-MS. Anal. Chem. 2015, 87, 967-974. [CrossRef] [PubMed]

62. McGrath, S.C.; Schieltz, D.M.; McWilliams, L.G.; Pirkle, J.L.; Barr, J.R. Detection and quantification of ricin in beverages using isotope dilution tandem mass spectrometry. Anal. Chem. 2011, 83, 2897-2905. [CrossRef] [PubMed]

63. Carr, S.; Aebersold, R.; Baldwin, M.; Burlingame, A.; Clauser, K.; Nesvizhskii, A. The need for guidelines in publication of peptide and protein identification data: Working group on publication guidelines for peptide and protein identification data. Mol. Cell Proteom. 2004, 3, 531-533. [CrossRef] [PubMed]

64. Mann, M.; Wilm, M. Error-tolerant identification of peptides in sequence databases by peptide sequence tags. Anal. Chem. 1994, 66, 4390-4399. [CrossRef] [PubMed]

65. Norbeck, A.D.; Monroe, M.E.; Adkins, J.N.; Anderson, K.K.; Daly, D.S.; Smith, R.D. The utility of accurate mass and LC elution time information in the analysis of complex proteomes. J. Am. Soc. Mass Spectrom. 2005, 16, 1239-1249. [CrossRef] [PubMed]

66. Thevis, M.; Loo, J.A.; Loo, R.R.; Schanzer, W. Recommended criteria for the mass spectrometric identification of target peptides and proteins $(<8 \mathrm{kDa})$ in sports drug testing. Rapid Commun. Mass Spectrom. 2007, 21, 297-304. [PubMed]

67. WADA-Laboratory-Committee. Identification criteria for qualitative assays incorporating column chromatography and mass spectrometry. WADA Tech. Doc. 2010, TD2010IDCR, 1-9.

68. OPCW Scientific Advisory Board. Report of the Nineteenth Session of the Scientific Advisory Board. Reports of the OPCW 2012; OPCW Scientific Advisory Board: The Hague, The Netherlands, 2012; pp. 1-39, SAB-19/1. 
69. Ovenden, S.P.; Fredriksson, S.-Å.; Bagas, C.K.; Bergström, T.; Thomson, S.A.; Nilsson, C.; Bourne, D.J. De novo sequencing of RCB-1 to -3: Peptide biomarkers from the castor bean plant Ricinus communis. Anal. Chem. 2009, 81, 3986-3996. [CrossRef] [PubMed]

70. Pauly, D.; Kirchner, S.; Störmann, B.; Schreiber, T.; Kaulfuss, S.; Schade, R.; Zbinden, R.; Avondet, M.A.; Dorner, M.B.; Dorner, B.G. Simultaneous quantification of five bacterial and plant toxins from complex matrices using a multiplexed fluorescent magnetic suspension assay. Analyst 2009, 134, 2028-2039. [CrossRef] [PubMed]

71. Popova, E.N. Interaction between Ricin and Hybridoma Cells Secreting Antibodies Specific for the Catalytic Subunit. Ph.D. Thesis, Lomonosov Moscow State University, Moscow, Russia, 2004.

72. Pauly, D.; Dorner, M.; Zhang, X.; Hlinak, A.; Dorner, B.; Schade, R. Monitoring of laying capacity, immunoglobulin $\mathrm{Y}$ concentration, and antibody titer development in chickens immunized with ricin and botulinum toxins over a two-year period. Poult. Sci. 2009, 88, 281-290. [CrossRef] [PubMed]

73. He, X.; McMahon, S.; Henderson, T.D., 2nd; Griffey, S.M.; Cheng, L.W. Ricin toxicokinetics and its sensitive detection in mouse sera or feces using immuno-PCR. PLoS ONE 2010, 5. [CrossRef] [PubMed]

74. Roy, C.J.; Hale, M.; Hartings, J.M.; Pitt, L.; Duniho, S. Impact of inhalation exposure modality and particle size on the respiratory deposition of ricin in BALB/c mice. Inhal. Toxicol. 2003, 15, 619-638. [CrossRef] [PubMed]

75. Koja, N.; Shibata, T.; Mochida, K. Enzyme-linked immunoassay of ricin. Toxicon 1980, 18, $611-618$. [CrossRef]

76. Poli, M.A.; Rivera, V.R.; Hewetson, J.F.; Merrill, G.A. Detection of ricin by colorimetric and chemiluminescence ELISA. Toxicon 1994, 32, 1371-1377. [CrossRef]

77. Griffiths, G.D.; Newman, H.; Gee, D.J. Identification and quantification of ricin toxin in animal tissues using ELISA. J. Forensic Sci. Soc. 1986, 26, 349-358. [CrossRef]

78. Leith, A.G.; Griffiths, G.D.; Green, M.A. Quantification of ricin toxin using a highly sensitive avidin/biotin enzyme-linked immunosorbent assay. J. Forensic Sci. Soc. 1988, 28, 227-236. [CrossRef]

79. Rubina, A.Y.; Dyukova, V.I.; Dementieva, E.I.; Stomakhin, A.A.; Nesmeyanov, V.A.; Grishin, E.V.; Zasedatelev, A.S. Quantitative immunoassay of biotoxins on hydrogel-based protein microchips. Anal. Biochem. 2005, 340, 317-329. [CrossRef] [PubMed]

80. Guglielmo-Viret, V.; Splettstoesser, W.; Thullier, P. An Immunochromatographic test for the diagnosis of ricin inhalational poisoning. Clin. Toxicol. 2007, 45, 505-511. [CrossRef] [PubMed]

81. Zhuang, J.; Cheng, T.; Gao, L.; Luo, Y.; Ren, Q.; Lu, D.; Tang, F.; Ren, X.; Yang, D.; Feng, J.; et al. Silica coating magnetic nanoparticle-based silver enhancement immunoassay for rapid electrical detection of ricin toxin. Toxicon 2010, 55, 145-152. [CrossRef] [PubMed]

82. Lang, L.; Wang, Y.; Wang, C.; Zhao, Y.; Jia, P.; Fu, F. Determination of ricin by double antibody sandwich enzyme-linked immunosorbent assay in different samples. J. Int. Pharm. Res. 2009, 36, 12-16.

83. Men, J.; Lang, L.; Wang, C.; Wu, J.; Zhao, Y.; Jia, P.Y.; Wei, W.; Wang, Y. Detection of residual toxin in tissues of ricin-poisoned mice by sandwich enzyme-linked immunosorbent assay and immunoprecipitation. Anal. Biochem. 2010, 401, 211-216. [CrossRef] [PubMed]

84. Gaylord, S.T.; Dinh, T.L.; Goldman, E.R.; Anderson, G.P.; Ngan, K.C.; Walt, D.R. Ultrasensitive detection of ricin toxin in multiple sample matrixes using single-domain antibodies. Anal. Chem. 2015, 87, 6570-6577. [CrossRef] [PubMed]

85. Jenko, K.L.; Zhang, Y.; Kostenko, Y.; Fan, Y.; Garcia-Rodriguez, C.; Lou, J.; Marks, J.D.; Varnum, S.M. Development of an ELISA microarray assay for the sensitive and simultaneous detection of ten biodefense toxins. Analyst 2014, 139, 5093-5102. [CrossRef] [PubMed]

86. Garber, E.A.; O'Brien, T.W. Detection of ricin in food using electrochemiluminescence-based technology. J. AOAC Int. 2008, 91, 376-382. [PubMed]

87. Simon, S.; Fiebig, U.; Liu, Y.; Tierney, R.; Dano, J.; Worbs, S.; Endermann, T.; Nevers, M.-C.; Volland, H.; Sesardic, D.; et al. Recommended immunological strategies to screen for botulinum neurotoxin-containing samples. Toxins 2015, 7. [CrossRef]

88. Vang, O.; Larsen, K.P.; Bøg-Hansen, T.C. A new quantitative and highly specific assay for lectinbinding activity. In Lectins; Walter de Gruyter \& Co.: Berlin, Germany, 1986; Volume 6, pp. 637-644. 
89. Ezan, E.; Duriez, E.; Fenaille, F.; Becher, F. Functional Assays for Ricin Detection. In Detection of Biological Agents for the Prevention of Bioterrorism; Banoub, J., Ed.; Springer Netherlands: Dordrecht, The Netherlands, 2011; pp. 131-147.

90. Bozza, W.P.; Tolleson, W.H.; Rosado, L.A.; Zhang, B. Ricin detection: Tracking active toxin. Biotechnol. Adv. 2015, 33, 117-123. [CrossRef] [PubMed]

91. Kopferschmitt, J.; Flesch, F.; Lugnier, A.; Sauder, P.; Jaeger, A.; Mantz, J.M. Acute voluntary intoxication by ricin. Hum. Toxicol. 1983, 2, 239-242. [CrossRef] [PubMed]

92. Kull, S.; Pauly, D.; Störmann, B.; Kirchner, S.; Stämmler, M.; Dorner, M.B.; Lasch, P.; Naumann, D.; Dorner, B.G. Multiplex detection of microbial and plant toxins by immunoaffinity enrichment and matrix-assisted laser desorption/ionization mass spectrometry. Anal. Chem. 2010, 82, 2916-2924. [CrossRef] [PubMed]

93. Becher, F.; Duriez, E.; Volland, H.; Tabet, J.C.; Ezan, E. Detection of functional ricin by immunoaffinity and liquid chromatography-tandem mass spectrometry. Anal. Chem. 2007, 79, 659-665. [CrossRef] [PubMed]

94. Halter, M.; Almeida, J.L.; Tona, A.; Cole, K.D.; Plant, A.L.; Elliott, J.T. A mechanistically relevant cytotoxicity assay based on the detection of cellular GFP. Assay Drug Dev. Technol. 2009, 7, 356-365. [CrossRef] [PubMed]

95. Wannemacher, R.W.; Anderson, J.B. Inhalation ricin: Aerosol procedures, animal toxicology, and therapy. In Inhalational Toxicology; Salem, H., Katz, S.A., Eds.; CRC Press Taylor \& Francis Group: Boca Raton, FL, USA, 2006; pp. 973-982.

96. Roy, C.J.; Song, K.; Sivasubramani, S.K.; Gardner, D.J.; Pincus, S.H. Animal models of ricin toxicosis. Curr. Top. Microbiol. Immunol. 2012, 357, 243-257. [PubMed]

97. Soler-Rodríguez, A.-M.; Uhr, J.W.; Richardson, J.; Vitetta, E.S. The toxicity of chemically deglycosylated ricin A-chain in mice. Int. J. Immunopharmacol. 1992, 14, 281-291. [CrossRef]

98. Yan, Q.; Li, X.P.; Tumer, N.E. N-glycosylation does not affect the catalytic activity of ricin A chain but stimulates cytotoxicity by promoting its transport out of the endoplasmic reticulum. Traffic 2012, 13, 1508-1521. [CrossRef] [PubMed]

99. Varki, A. Biological roles of oligosaccharides: All of the theories are correct. Glycobiology 1993, 3, 97-130. [CrossRef] [PubMed]

100. Meagher, M.M.; Seravalli, J.G.; Swanson, S.T.; Ladd, R.G.; Khasa, Y.P.; Inan, M.; Harner, J.C.; Johnson, S.K.; Van Cott, K.; Lindsey, C.; et al. Process development and cGMP manufacturing of a recombinant ricin vaccine: An effective and stable recombinant ricin A-chain vaccine-RVEc. Biotechnol. Prog. 2011, 20, 1036-1047. [CrossRef] [PubMed]

(C) 2015 by the authors; licensee MDPI, Basel, Switzerland. This article is an open access article distributed under the terms and conditions of the Creative Commons by Attribution (CC-BY) license (http:/ / creativecommons.org/licenses/by/4.0/). 